\title{
The Piedra Chamana fossil woods (Eocene, Peru), II
}

\author{
D.W. Woodcock ${ }^{1, *}$, H.W. Meyer ${ }^{2}$, and Y. Prado ${ }^{3}$ \\ ${ }^{1}$ Marsh Institute of Clark University, 650 Main Street, Worcester, MA 01610, U.S. A. \\ ${ }^{2}$ U.S. National Park Service, Florissant Fossil Beds National Monument, P. O. Box 185, \\ Florissant, CO 80816, U.S. A. \\ ${ }^{3}$ Museo de Historia Natural, Universidad Nacional Mayor de San Marcos, Av. Arenales 1256, \\ Lima 14, Peru. \\ *Corresponding author; e-mail: dwoodcock@clarku.edu
}

Accepted for publication: 13 November 2018 - Available online: January 2019

\begin{abstract}
This contribution presents descriptions of 14 fossil woods from the Piedra Chamana Fossil Forest in Peru, an assemblage of fossil woods and leaves dated at $39 \mathrm{Ma}$ (late Middle Eocene). It is part two of the descriptions of the non-monocot angiosperm fossils from the site (see Woodcock et al. 2017). The woods are assigned to the subfamilies Bombacoideae, Bombacoideae/ Malvoideae, Byttneroideae, Grewioideae, and Sterculioideae of Malvaceae and the families Melastomataceae, Muntingiaceae, Rubiaceae, Rutaceae, and Sapindaceae. Malvalean taxa make up around one-third of the wood types. Many of the woods are identifiable to modern-day genera or groups, including genera with species counted among the hyperdominant trees of the New World forests. Represented vegetation types include mixed freshwater swamp with Avicennia, seasonally flooded forest, and lowland tropical forest with a dry aspect. The assemblage shows floristic similarities to extant South American lowland tropical forest, particularly the seasonally flooded forests growing along white water rivers (várzea); however, the dry forest association has a less clear analog in the present-day tropics.
\end{abstract}

Fossil forest, Sexi, Peruvian Andes, coastal mangrove forest, seasonally flooded forest, dry tropical forest.

\section{INTRODUCTION}

The Piedra Chamana fossils are a 39 Ma assemblage of fossil woods and leaves preserved in ashfall and volcanic flow deposits at a site in northern Peru (Woodcock et al.2009). Descriptions of 17 of the non-monocot angiosperm wood types represented in the assemblage were published in an earlier contribution (Woodcock et al. 2017), which includes information about the geological and paleontological context. Woods described previously were referred to the families Acanthaceae, Anacardiaceae ( 2 wood types), Apocynaceae, Combretaceae, Cordiaceae (3 wood types), Dipterocarpaceae, Euphorbiaceae, Fabaceae (3 wood types), Lecythidaceae, and Lythraceae (3 wood types). These identifications establish that the vegetation was lowland tropical forest 
growing in a coastal location (one of the taxa present is the mangrove genus Avicennia). Included here are descriptions of an additional 14 wood types, which are referred to the families Malvaceae, Melastomataceae, Muntingiaceae, Rubiaceae, Rutaceae, and Sapindaceae.

Information sources utilized include databases for woods and fossil woods, primarily InsideWood (2004-onwards, see also Wheeler 2011) and Richter \& Dallwitz (2000-onwards); published anatomical descriptions; regional wood atlases including Détienne \& Jaquet (1983), Acevedo \& Kikata (1994), and Sonsin et al. (2014); the list of fossil wood names compiled in Gregory et al. (2009); and wood slides collections at Harvard (Bailey-Wetmore Wood and Slide Collection, Aw) and those of the first author. Analyses of affinity 1) provide a list of coded characters in the InsideWood database that are unique to the fossil and taxa under consideration as closest relatives, and 2) discuss proposed affinities with reference to a) wood-anatomical characteristics at the species, genus, and supra-generic levels, b) dissimilarities with respect to the coded IAWA characters, and c) similarities and dissimilarities with respect to other, non-coded characters. Modern woods are the most important point of comparison because of the amount of information available in databases, published descriptions, and systematic treatments, but fossil woods are also considered where affinity is suggested. In most cases, the fossil woods show greatest correspondence with modern woods and are named to extant genera. One wood is referred to a previously described fossil taxon (Grewinium canalisum (Bande \& Srivastava) Srivastava \& Guleria), and one to a newly established form genus (Miconioidea). Characterization of the occurrence and ecology of the represented taxa draws on sources including the Global Biodiversity Information Facility database (GBIF 2001-onwards), the Useful Tropical Plants database (tropical. theferns.info), and regional floras including Gentry (1993) and Pennington et al. (2004). The Plant List (2010) was used to verify nomenclature and for information about species diversity of genera.

\section{DESCRIPTIONS AND ATTRIBUTIONS}

\section{Malvaceae}

Nine of the wood types show closest correspondence to Malvaceae, a large, diverse group currently under taxonomic revision (Stevens 2001-onwards). Woods in the order Malvales generally have non-septate fibers and apotracheal parenchyma that is diffuse or diffuse-in-aggregates to banded (InsideWood 2004-onwards). Rays with tile cells are restricted almost entirely to Malvaceae, only being reported as variably present in one genus of Dipterocarpaceae (InsideWood 2004-onwards). However, tile cells are not universally present in Malvaceae and do not occur in some subfamilies. Designations as to tile cell type are as outlined in Manchester and Miller (1978): Durio type approximately the same height as procumbent cells, and usually very narrow in tangential section (Chattaway 1933); Intermediate type - somewhat to two times the height of the procumbent cells; and Pterospermum type - two or more times the height of the procumbent cells. Note that these definitions differ from those in the IAWA features list (IAWA Committee 1989) and also that determinations in the literature, particularly for the Intermediate and Pterospermum types, may be inconsistent; comparisons made 
here rely on photographs or the wood slides collections consulted. In Malvaceae, intervessel and vessel-axial parenchyma pits are often similar, but when they differ, vessel-parenchyma pitting generally consists of pits approximating the intervessel pits in size intermixed in the same cells with pits that are simple or with reduced borders and variably enlarged. Table 1 presents information on anatomical characteristics of the subfamilies of Malvaceae based mainly on information in the InsideWood database (InsideWood 2004-onwards) and with family groups as constituted on the Angiosperm Phylogeny website (Stevens 2001-onwards) and in recent taxonomic treatments. The information presented should be considered provisional pending more systematic review of the wood anatomy of the family.

\section{Malvaceae - Bombacoideae}

CEIBA Mill.

Ceiba archeopentandra Woodcock, Meyer et Prado, sp.nov. (Fig. 1)

Diagnosis: Growth rings absent or indistinct, wood diffuse porous. Vessels solitary and in short radial multiples, mean tangential diameter 150-200 $\mu \mathrm{m}$; intervessel pits alternate; vessel-ray parenchyma pits variable within individual cells, similar in size and shape to intervessel pits to enlarged and circular to elongate. Fibers non-septate. Axial parenchyma vasicentric and diffuse-in-aggregates. Rays non-storied, 1-7-seriate, with procumbent body ray cells, sheath cells, and 1-2 rows of square to upright marginal cells. Vessel elements and axial parenchyma storied.

Etymology: The fossil is named for its similarity to Ceiba pentandra.

Holotype: USM-S15/S16 (diameter $10 \mathrm{~cm}$ ). Other material: USM-S5 (diameter $24 \mathrm{~cm})$.

Type locality: Piedra Chamana Fossil Forest main site, associated with the volcanic flow deposits.

Description: Growth rings absent or indistinct and then marked by changes in density and diameter of axial parenchyma. Wood diffuse porous (Fig. 3A). Vessels solitary and in radial multiples of $2-4(5)$, tangential diameter $177 \pm 33 \mu \mathrm{m}$, frequency $\sim 4 / \mathrm{mm}^{2}$, mostly round in outline, perforations simple; intervessel pits crowded alternate, polygonal to round, with round apertures (Fig. 1C), 7.5-10 $\mu \mathrm{m}$; vessel-ray parenchyma and -axial parenchyma pits variable within individual cells, similar in size and shape to intervessel pits to enlarged and circular to elongate (Fig. 1D); vessel element length $424 \pm 53 \mu \mathrm{m}$. Fibers non-septate, thin- to thick-walled, isolated and in short bands, narrower than axial parenchyma (Fig. 1B), pitting not observed. Axial parenchyma vasicentric, also diffuse-in-aggregates, in bands 1-2 cells wide (Fig. 1B); strands 2-4 (8) cells long (Fig. 1G). Rays 1-7-seriate; uniseriate rays frequent, composed mostly of upright to square cells, 3-16 cells long; multiseriate rays composed of low to very low procumbent body ray cells, sheath cells, and 1-2 (4) rows of square to upright marginal cells (Fig. 1E, F), height $1835 \pm 1058 \mu \mathrm{m}$, frequency $\sim 3 /$ tangential mm. Rays often fused vertically. Vessel elements and axial parenchyma storied (Fig. 1G).

Affinity. In the InsideWood database, the combination of vessel-ray parenchyma pits with reduced borders to apparently simple/pits rounded or angular, vessels $\leq 5 / \mathrm{mm}^{2}$, diffuse-in-aggregates parenchyma, larger rays 4-10-seriate, sheath cells present, tile 
Table 1. Wood-anatomical characteristics of Malvaceae subfamilies.

Subfamilies/taxa represented in the assemblage in boldface. Abbreviations: DP $=$ diffuse porous, $\mathrm{Vdia}=$ vessel diameter, $\mathrm{Vden}=$ vessel density, $\mathrm{RP} / \mathrm{SRP}=$ ring porous to semi-ring porous, Vx's = vessels in radial multiples, IV pit $=$ intervessel pit, VP pits $=$ vessel-parenchyma pits. Ray width categories: $1=1$ to 3 cells, $2=$ larger rays 4 - to 10 -seriate, $3=$ larger rays $>10$-seriate.

\begin{tabular}{|c|c|c|c|c|c|c|c|c|}
\hline & 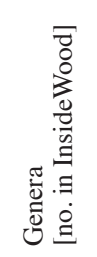 & 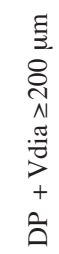 & 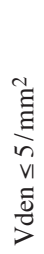 & $\begin{array}{l}\frac{a}{\sqrt{n}} \\
\frac{a}{a}\end{array}$ & 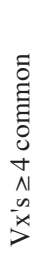 & 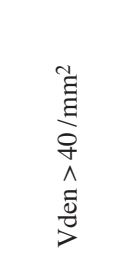 & $\begin{array}{l}\stackrel{\mathbb{N}}{2} \\
\cdot \frac{1}{2} \\
\geq\end{array}$ & 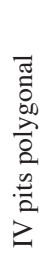 \\
\hline $\begin{array}{c}\text { Byttneroideae } \\
\text { (Whitlock et al. 2001) }\end{array}$ & $23[10]$ & - & \pm & - & - & - & min-small & $+?$ \\
\hline $\begin{array}{c}\text { Grewioideae } \\
\text { (Brunken \& Mueller } \\
\text { 2012) }\end{array}$ & 25 [19] & \pm & \pm & $\begin{array}{l}\text { Grewia, } \\
\text { Luehea }\end{array}$ & \pm & Grewia & small-med & $-?$ \\
\hline $\begin{array}{c}\text { Helicteroideae } \\
\text { (Nyffeler \& Baum } \\
\text { 2000) }\end{array}$ & 10 [7] & \pm & \pm & Reevesia & \pm & Mansonia & min-small & $-?$ \\
\hline $\begin{array}{c}\text { Brownlowiodeae } \\
\text { (Stevens } \\
\text { 2001-onwards) }\end{array}$ & $9[7$ & rare & \pm & - & \pm & - & $\min (-$ small $)$ & $-?$ \\
\hline $\begin{array}{c}\text { Sterculioideae } \\
\text { (Wilkie } \text { et al. 2006) }\end{array}$ & 13 [11] & \pm & \pm & rare $^{2}$ & - & - & min-small & $-?$ \\
\hline $\begin{array}{l}\text { Dombeyoideae } \\
\quad \text { (Stevens } \\
\text { 2001-onwards) }\end{array}$ & 21 [5] & rare & \pm & Helmiopsis & \pm & \pm & min-small & $+?$ \\
\hline $\begin{array}{c}\text { Tilioideae } \\
\text { (Stevens } \\
\text { 2001-onwards) }\end{array}$ & $3[2]$ & - & - & rare $^{3}$ & - & Tilia & min-small & \pm \\
\hline $\begin{array}{l}\text { Malvoideae }^{1} \\
\quad \text { (Stevens } \\
\text { 2001-onwards) }\end{array}$ & $\begin{array}{c}90+ \\
{[14 ?]}\end{array}$ & - & \pm & rare $^{4}$ & \pm & $\begin{array}{l}\text { Abutilon } \\
\text { Hibiscus }\end{array}$ & min-small & $?$ \\
\hline Ochroma & & + & + & - & - & - & med-large & $\pm ?$ \\
\hline $\begin{array}{l}\text { Bombacoideae }^{1} \\
\text { (Carvalho-Sobrino } \\
\text { et al. 2016) }\end{array}$ & $16[3]$ & \pm & \pm & $\operatorname{rare}^{5}$ & - & - & med-large & + \\
\hline
\end{tabular}

1 Omitting Ochroma.

${ }^{2}$ One temperate-latitude genus (Firmania).

${ }^{3}$ Temperate-latitude Cragia.

4 Tropical to temperate species of Hibiscus.

5 Temperate-latitude Fremontodendron . 
(Table 1 continued)

\begin{tabular}{|c|c|c|c|c|c|c|c|c|c|c|}
\hline \multirow{2}{*}{ 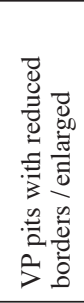 } & \multirow[t]{2}{*}{ 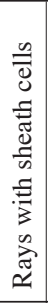 } & \multirow{2}{*}{ 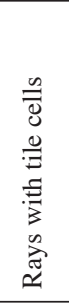 } & \multirow{2}{*}{ 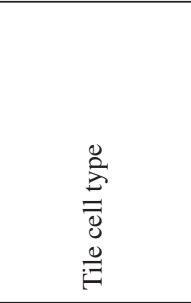 } & \multicolumn{3}{|c|}{ Ray width } & \multirow{2}{*}{ 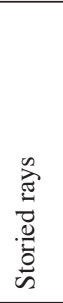 } & \multirow{2}{*}{ 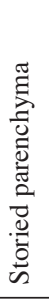 } & \multirow[t]{2}{*}{ 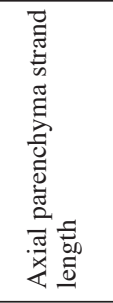 } & \multirow[b]{2}{*}{ Other characters } \\
\hline & & & & 1 & 2 & 3 & & & & \\
\hline - & \pm & \pm & Intermediate & + & + & & \pm & \pm & $2-8$ & \\
\hline rarely & \pm & \pm & $\begin{array}{l}\text { Intermediate to } \\
\text { Pterospermum }\end{array}$ & + & + & & \pm & \pm & (1)2-8(+) & $\begin{array}{l}\text { Apotracheal parenchyma } \\
\text { often very sparsely diffuse/ } \\
\text { diffuse-in-aggregates, some- } \\
\text { times paratracheal-aliform }\end{array}$ \\
\hline - & \pm & \pm & $\begin{array}{l}\text { Dario to } \\
\text { Intermediate }\end{array}$ & + & + & \pm & & \pm & $1-8+$ & \\
\hline \pm & - & - & & + & + & & + & \pm & $4-8+$ & \\
\hline \pm & + & - & & & + & + & rare? & \pm & $2-4$ & $\begin{array}{l}\text { Body ray cells very narrow } \\
\text { in tangential view; vasicen- } \\
\text { tric parenchyma }\end{array}$ \\
\hline - & \pm & \pm & $\begin{array}{l}\text { Pterospermum } \\
\text { (Pterospermum) }\end{array}$ & + & + & & \pm & \pm & $2-4(8)$ & \\
\hline - & - & \pm & $\begin{array}{l}\text { Intermediate to } \\
\text { Pterospermum }\end{array}$ & + & + & & -4 & -4 & $2-8$ & \\
\hline - & \pm & rare & Pterospermum & + & + & & \pm & \pm & $1-4(8)$ & \\
\hline+ & $\begin{array}{l}+ \\
\pm\end{array}$ & $\begin{array}{c}+ \\
\text { rare? }\end{array}$ & Pterospermum & & + & & $\begin{array}{l}- \\
\text { rare }\end{array}$ & - & $\begin{array}{l}2-4(8) \\
(1) 2-8(+)\end{array}$ & $\begin{array}{l}\text { Fibers generally narrow } \\
\text { relative to parenchyma }\end{array}$ \\
\hline
\end{tabular}



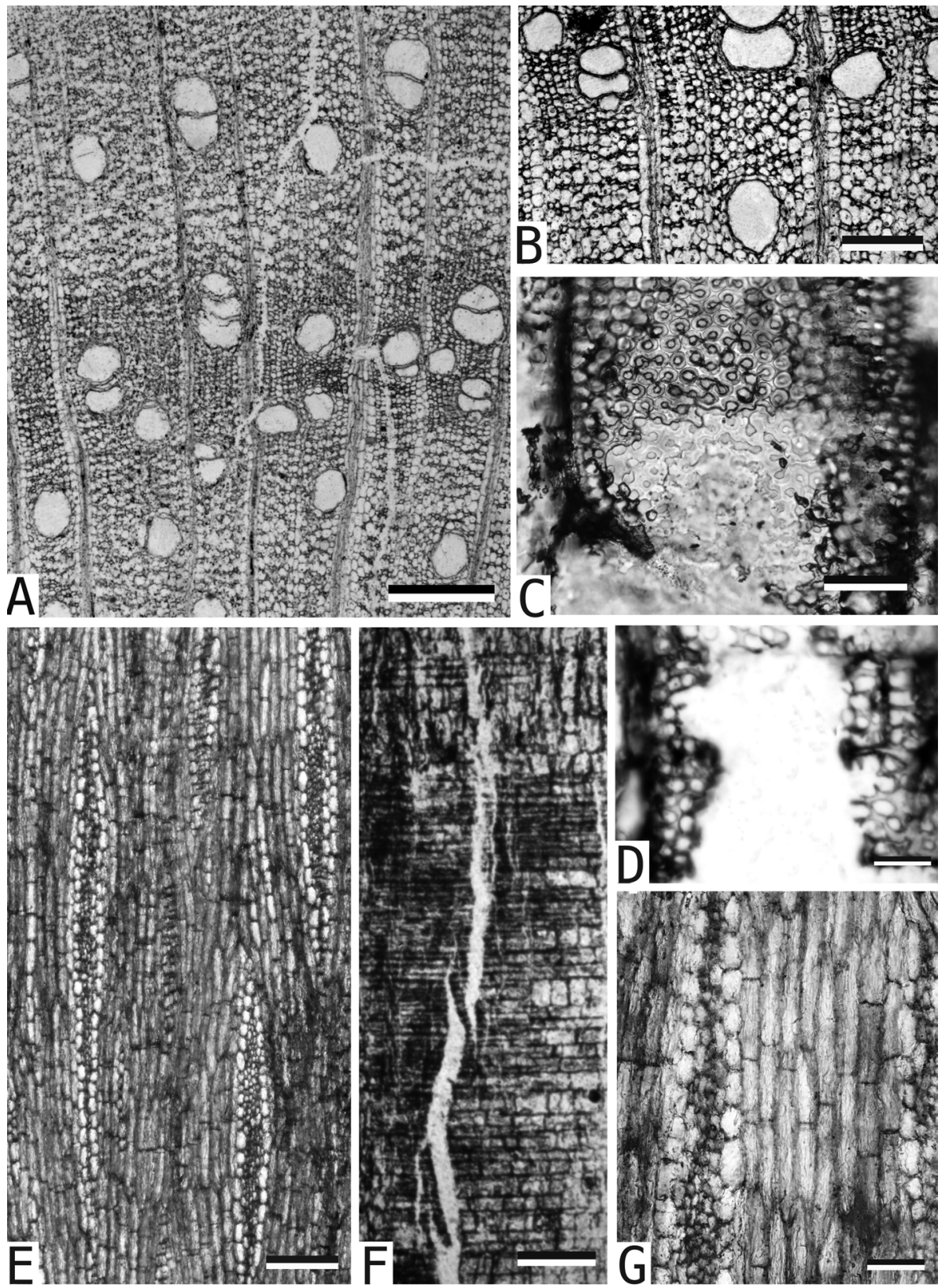

Figure 1. Ceiba archeopentandra Woodcock, Meyer et Prado, sp. nov. USM-S15/S16. A: Vessels solitary and in short multiples, TS. - B: Diffuse-in-aggregates parenchyma, TS. C: Intervessel pits alternate, circular to polygonal, TLS. - D: Vessel-ray parenchyma pits variably enlarged, RLS. - E: Rays 1-7-seriate with sheath cells, TLS. - F: Heterocellular ray, RLS. G: Axial parenchyma in strands of 2-4 and storied, TLS. - Scale bars $=500 \mu \mathrm{m}$ in A, $250 \mu \mathrm{m}$ in $\mathrm{B}, \mathrm{E} ; 100 \mu \mathrm{m}$ in $\mathrm{F}, \mathrm{G} ; 25 \mu \mathrm{m}$ in $\mathrm{C}, \mathrm{D}$. 
cells absent, and axial parenchyma and/or vessel elements storied (IAWA characters 31, 46, 77, 98, 110, 120 with 111 absent) occurs only in Malvaceae - in Bombacoideae (Adansonia, Bombax, Cavanillesia, Ceiba, Chiranthodendron, Pachira) and Sterculioideae (Brachychiton, Sterculia). Bands of very narrow fibers (Détienne et al. 1983) and intervessel pits (crowded alternate and) polygonal (Table 1) support affinity with Bombacoideae. Ceiba, particularly C. pentandra (L.) Gaertn., shares the most characters with the fossil. This is a genus of 20 species with an exclusively New World distribution except for $C$. pentandra, which has a range extending to Africa. It includes small to very large, often emergent forest trees occurring in lowland dry to mesic and seasonally flooded forests (Gentry 1993; Wittmann et al. 2010). The genus, like most Bombacoideae, shows variability in abundance of axial parenchyma and presence/ absence of parenchyma bands and marginal parenchyma based on study of material in wood slide collections (Aw). Détienne and Jacquet (1983) and Détienne et al. (1983) do not describe tile cells for Bombacaceae/Bombacoideae, and most descriptions of Ceiba do not include tile cells; however, some material (e.g., Chorisia - now Ceiba) in the wood slides collections consulted (Aw) appear to have tile cells. Similarities to C.pentandra include rays commonly fused vertically, parenchyma and fiber bands 1 cell wide, and frequent uniseriate rays; one difference is that $C$. pentandra has crystals in axial parenchyma and rays (Richter \& Dallwitz 2000-onward; InsideWood 2004-onwards). Cavanillesia is also similar but has a higher proportion of axial parenchyma relative to fibers/wide parenchyma bands (Richter \& Dallwitz 2000-onwards; InsideWood 2004-onwards). The other Bombacoid taxa listed above differ mainly in that they lack parenchyma with two cells per strand; most species of Pachira also have silica bodies in rays and crystals (InsideWood 2004-onwards). Some species of Sterculia (Sterculioideae) are also similar but this subfamily generally has wider rays; also when vessel-ray parenchyma pits are enlarged, as in some Sterculia, they generally have reduced borders.

The combination of vessel-ray parenchyma pits with much reduced borders to apparently simple, diffuse-in-aggregates parenchyma, and rays with sheath cells (IAWA characters 300,77, and 110) does not occur in any fossil wood referred to Malvaceae in the InsideWood database. There are few records of fossil bombacoid woods in the Neotropics, where the subfamily is thought to have originated (Baum et al. 2004).

The fossil is referred to a new species of Ceiba based on its correspondence to the genus, particularly $C$. pentandra.

Ceiba huancabambiana Woodcock, Meyer et Prado, sp.nov. (Fig. 2)

Diagnosis: Wood with growth rings, diffuse porous. Vessels solitary and in short radial multiples, mean tangential diameter $100-150 \mu \mathrm{m}$, perforations simple; intervessel pits alternate; vessel-ray parenchyma pits variable within individual cells, simple, similar in size to intervessel pits to enlarged. Fibers non-septate. Axial parenchyma scanty paratracheal to vasicentric, diffuse-in-aggregates to banded, and in marginal bands. Rays non-storied, 1-9-seriate with procumbent body ray cells, sheath cells, and 1-4 rows of marginal cells. Axial parenchyma, vessel elements, and fibers storied. 

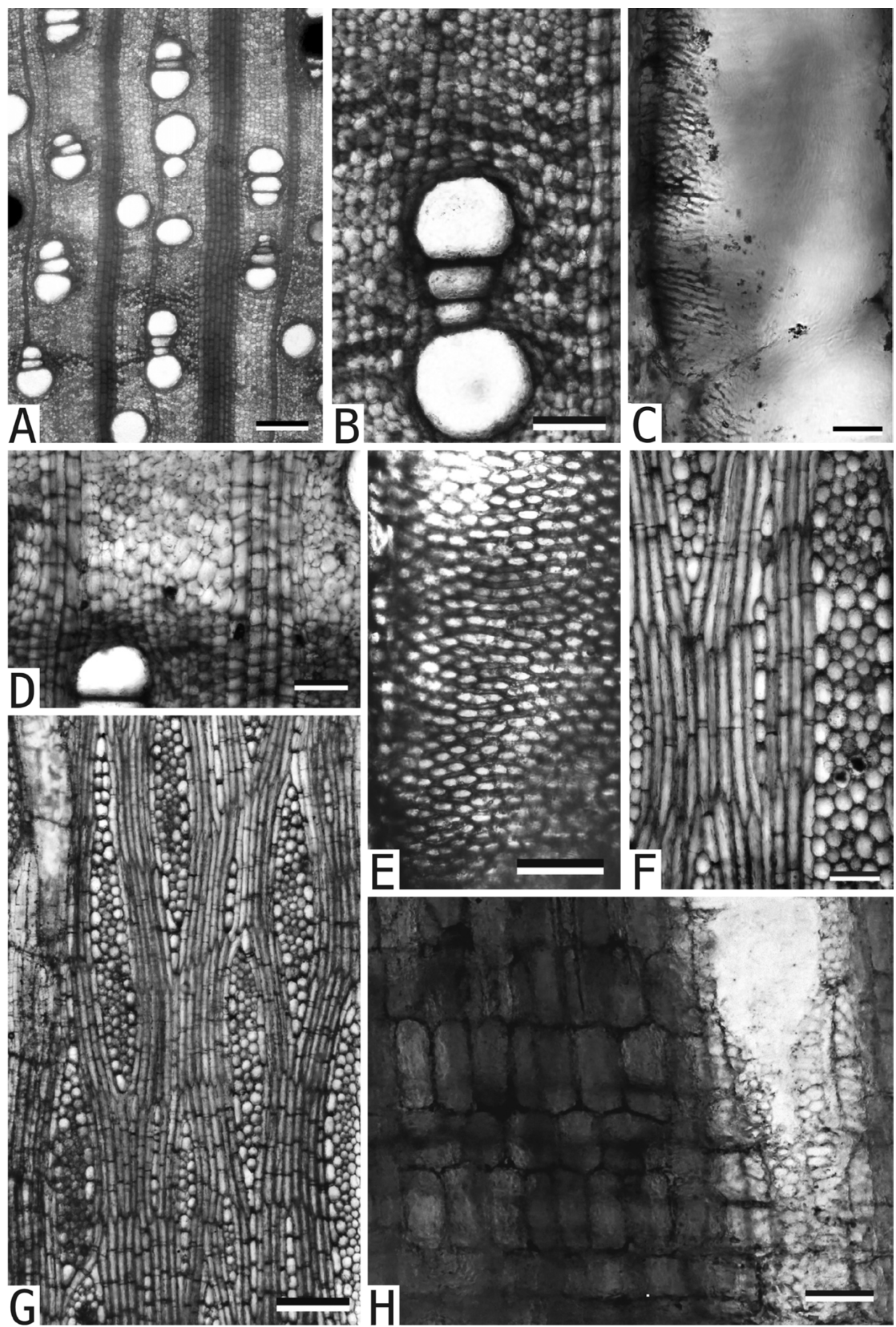

Figure 2. Ceiba huancabambiana Woodcock, Meyer et Prado, sp.nov. USM-S141. - A: Vessels solitary and in short radial multiples, TS. - B: Axial parenchyma diffuse-in-aggregates, TS. C: Vessel with wall sculpturing, TLS. - D: Marginal parenchyma, TS. - E: Intervessel pits alternate, TLS. - F: Axial parenchyma storied, in strands of 2-4, TLS. - G: Rays 1-5-seriate with sheath cells, TLS. - H: Heterocellular ray, vessel-ray parenchyma pits variably enlarged, RLS. - Scale bars $=250 \mu \mathrm{m}$ in A, G; $100 \mu \mathrm{m}$ in B, D, F; $50 \mu \mathrm{m}$ in C, E, H. 
Etymology: The species is named for the Huancabamba-Amotape Biogeographic Zone in southern Ecuador and northern Peru.

Holotype: USM-S141 (diameter $4 \times 4.5 \mathrm{~cm}$ ).

Type locality: Piedra Chamana Fossil Forest main site, associated with the volcanic flow deposits.

Description: Growth rings present, marked by radially flattened cells (fibers and parenchyma) and marginal parenchyma (Fig. 2D). Wood diffuse porous. Vessels solitary and in radial multiples of 2-4 (Fig. 2A, B), tangential diameter $132 \pm 22 \mu \mathrm{m}$, frequency $\sim 9 / \mathrm{mm}^{2}$, circular in outline, perforations simple, end walls horizontal to oblique; lateral walls with wall sculpturing, sometimes anastomosing (Fig. 2C); intervessel pits crowded alternate, polygonal to somewhat elongate (Fig. 2E), 10-12.5 $\mu \mathrm{m}$; vesselray parenchyma and -axial parenchyma pits variable within individual cells, simple, similar in size and shape to intervessel pits to enlarged, circular to elongate (Fig. $2 \mathrm{H}$ ); vessel element length $427 \pm 87 \mu \mathrm{m}$. Fibers non-septate, thin- to thick-walled, pitting not observed, width approximating or somewhat narrower than axial parenchyma. Axial parenchyma scanty paratracheal to vasicentric, also diffuse-in-aggregates to irregularly banded (Fig. 2B); bands 1-2 (4-5) cells wide alternating with 1(-2)-cell-wide bands of narrow fibers; also in apparently marginal bands 4-5 cells wide; strands (2-) 4 cells cells long (Fig. 2F). Rays 1-9-seriate; uniseriate rays frequent, composed of mostly upright cells, 1-4 (10) cells high; multiseriate rays composed of procumbent body ray cells, sheath cells, and 1-4 rows of marginal cells (Fig. 2G, H); sheath and marginal cells square to upright and high to very high; ray height $1361 \pm 844 \mu \mathrm{m}$, frequency $\sim 3$ /tangential mm. Rays often aggregate or fused vertically. Axial parenchyma, vessel elements, and fibers storied. Vessels with light- and dark-colored contents.

Affinity. In the InsideWood database, the combination of large intervessel pits, parenchyma diffuse-in-aggregates and marginal, larger rays 4-10-seriate, sheath cells, and axial parenchyma and/or vessel elements storied (IAWA characters 27, 77, 89, 98, 110, 120) occurs only in Malvaceae - Bombacoideae [Adansonia, Ceiba, Chorisia (now Ceiba)]. Other features supporting affinity with Bombacoideae within Malvaceae are reduced border vessel-ray parenchyma pits, non-storied rays, and absence of tile cells (Table 1; Détienne et al. 1983). Intervessel pits that are crowded alternate and polygonal and medium to large and bands of fibers that are narrow relative to the associated apotracheal parenchyma (Détienne et al. 1983) may characterize Bombacoideae within the family (Table 1). Wall sculpturing occurs in some bombacoid taxa (InsideWood 2004onwards), although most taxa have wider vessels (>200 $\mu \mathrm{m})$ and crystals. Ceiba includes taxa (Ceiba speciosa (A.St.-Hil., A.Juss. \& Cambess.) P. Ravenna, C.insignis (Kunth) P.E. Gibbs \& J. Semir - both formerly Chorisia) with vessels 100-200 $\mu \mathrm{m}$ and marginal parenchyma bands (photos in InsideWood 2004-onwards; Acevedo \& Kikata 1994) like the fossil but with crystals in rays and/or axial parenchyma. Adansonia also shares many characters but has wider vessels and axial parenchyma strands 4-8 cells long.

The fossil differs from the previous wood type ( $C$. archeopentandra) in having narrower, more densely arranged vessels, larger pits, axial parenchyma primarily in strands of 4 , lower rays, wide bands of marginal parenchyma, and dark contents in vessels.

The fossil is referred to a new species of Ceiba based on characters shared with this genus. 

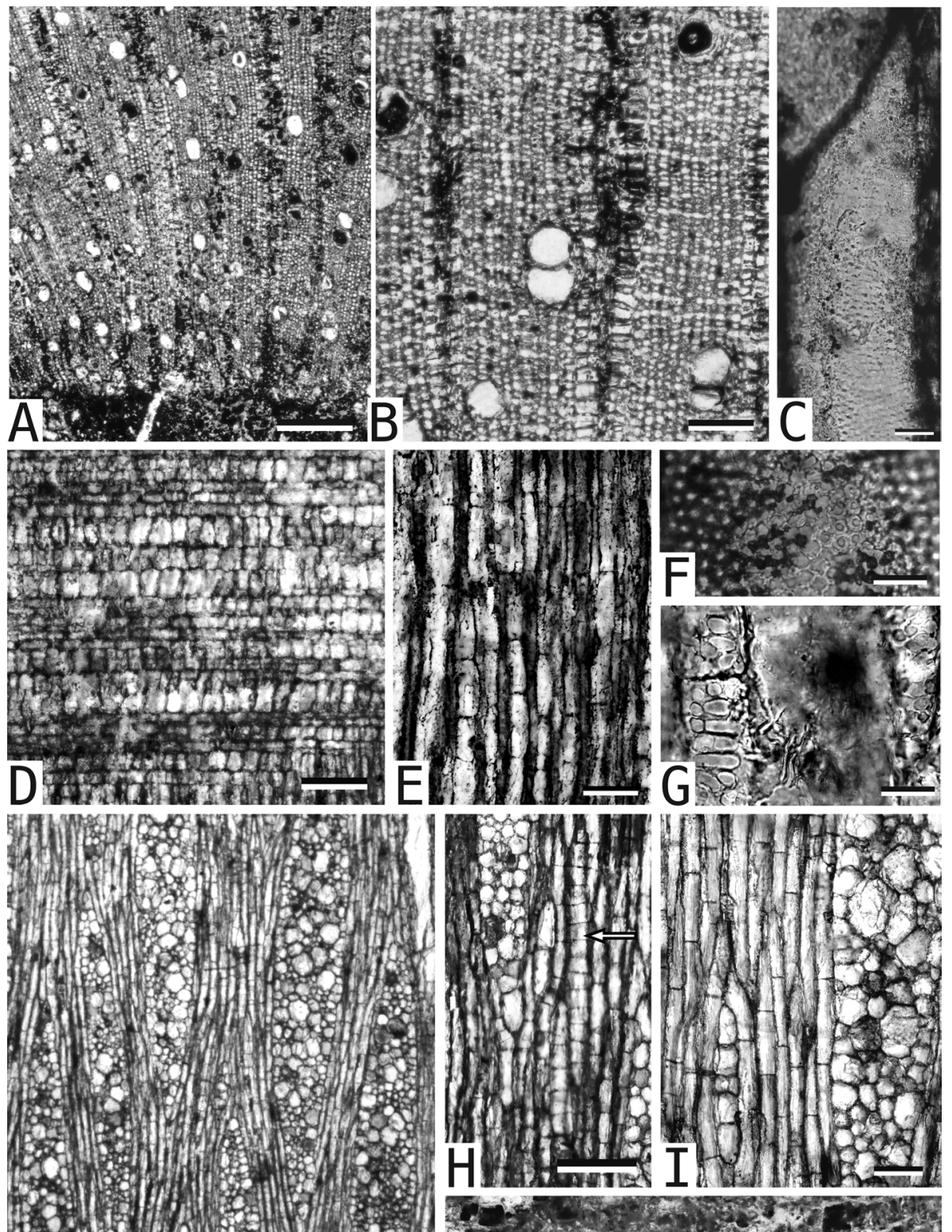

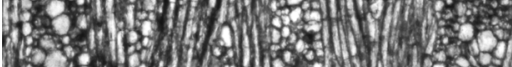

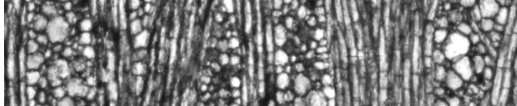

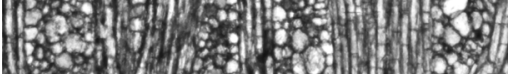

(3. 8.

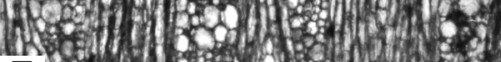

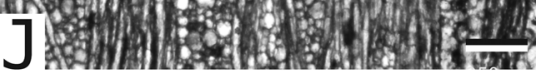

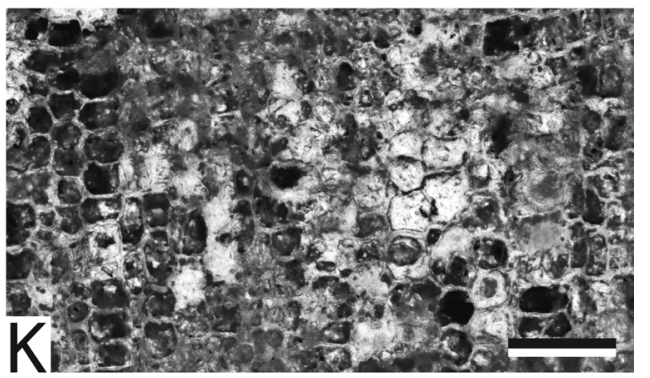




\section{Malvaceae - Bombacoideae/Malvoideae}

\section{OCHROMA Sw.}

Ochroma pozoensis Woodcock, Meyer et Prado, sp. nov. (Fig. 3)

Diagnosis: Growth rings absent or indistinct, wood diffuse porous. Vessels solitary and in radial pairs, mean tangential diameter 100-150 $\mu \mathrm{m}$, perforations simple; intervessel pits alternate; ray-vessel parenchyma pits variable within individual cells, similar in size and shape to intervessel pits to enlarged. Fibers non-septate. Axial parenchyma scanty paratracheal and diffuse-in-aggregates. Rays non-storied, 1-10-seriate, composed of procumbent body ray cells, tile cells of the Pterospermum type, and one row of square to upright marginal cells, tallest rays $>2 \mathrm{~mm}$. Pith parenchymatous.

Etymology: The specific epithet refers to the Pozo embayment, a marine incursion in northern Peru during the later Eocene.

Holotype: USM-S58 (4 cm diameter). Other material: USM-S91 (diameter $14 \times$ $19 \mathrm{~cm}$ - in situ in the ashfall deposit), USM-S102 $(15 \mathrm{~cm})$.

Type locality: Piedra Chamana Fossil Forest main site, Sexi, Peru, associated with the volcanic flow deposits.

Description: Growth rings absent/indistinct. Wood diffuse porous. Vessels solitary and in radial multiples of 2 (3) (Fig. 3 A,B), tangential diameter $112 \pm 19 \mu \mathrm{m}$, frequency $\sim 2-3 / \mathrm{mm}^{2}$, vessels round in outline, perforations simple; intervessel pits crowded alternate, polygonal (Fig. $3 \mathrm{~F}$ ), $\sim 8 \mu \mathrm{m}$; vessel-ray parenchyma and -axial parenchyma pits variable within individual cells, similar in size and shape to intervessel pits and appearing bordered to simple, enlarged, and rounded or elongate (Fig. 3G); vessel element length $385 \pm 84 \mu \mathrm{m}$; vessel elements with long tails (Fig. 3C). Fibers non-septate, very thin-walled, similar to axial parenchyma in tangential diameter $(35-40 \mu \mathrm{m})$ (Fig. 3 B); pitting not observed. Axial parenchyma scanty paratracheal to vasicentric and diffuse-in-aggregates, mostly in bands one cell wide alternating with 1-2-cellwide fiber bands (Fig. 3 B, E); in strands mostly 2-4 cells long (Fig. 3 I), paratracheal parenchyma strands longer ("vessel-contact strands", 8-14 cells long) and composed of shorterß cells, or possibly chambered (Fig. 3 H). Rays 1-10-seriate (Fig. 3 J); uniseriate rays infrequent, of mostly square to upright cells, $1-5$ cells high; wider rays composed of procumbent body ray cells, tile cells, and generally 1 (2-3) row of square (to upright?) marginal cells, from $2-3$-seriate and low (5-8 cells high) to $8-10$-seriate and high (>2 mm high); tile cells square to upright, $3-4 \times$ higher than procumbent cells (Fig. 3D), meeting the criteria for Pterospermum type although wide in radial section; height $2214 \pm 857 \mu \mathrm{m}$, frequency $\sim 2.5$ /tangential $\mathrm{mm}$. Rays frequently fused verti-

Figure 3. Ochroma pozoensis Woodcock, Meyer et Prado, sp.nov. USM-S58. - A: Diffuse-porous wood with pith, TS. - B: Diffuse-in-aggregates parenchyma, fiber diameter similar to that of axial parenchyma, TS. - C: Vessel element with long tail, TLS. - D: Rays with tile cells, RLS. E: Parenchyma alternating with fibers, RLS. - F: Crowded alternate intervessel pits, TLS. G: Vessel-axial parenchyma pits variably enlarged, RLS. - H: Long (chambered) paratracheal parenchyma strand (arrow), TLS. - I: Non-storied axial parenchyma in strands of 2-4, TLS. J: Non-storied rays, TLS. - K: Pith cells, RLS. - Scale bars $=250 \mu \mathrm{m}$ in A, D, J; $200 \mu \mathrm{m}$ in $\mathrm{B}, \mathrm{H}, \mathrm{K} ; 100 \mu \mathrm{m}$ in $\mathrm{E}, \mathrm{I} ; 40 \mu \mathrm{m}$ in $\mathrm{C} ; 25 \mu \mathrm{m}$ in $\mathrm{F}, \mathrm{G}$. 
cally. Pith present, appearing partly crushed in transverse section, parenchymatous, cells 40-70 $\mu \mathrm{m}$ in diameter, frequently with dark contents (Fig. 3 A, K).

Affinity. Presence of tile cells is a strong indication of Malvaceae. In the InsideWood database, the combination of vessels $\leq 5 / \mathrm{mm}^{2}$, axial parenchyma in strands of 2-4, wider rays 4-10-seriate, rays $>1 \mathrm{~mm}$ high, tile cells, and wood non-storied (IAWA characters 46, 91, 92, 98, 102, 111 with 118-122 absent) occurs only in Ochroma. Other shared characters are tile cells $>2 x$ higher than procumbent cells (Pterospermum type) and vertically fused rays (Richter \& Dallwitz 2000-onwards). Ochroma is variable with respect to proportion of axial parenchyma and fiber length (Détienne et al. 1983; Richter \& Dallwitz 2000-onwards; InsideWood 2004-onwards), but the fossil has vessels that are narrow relative to the genus and the appearance of the tile cells (round rather than rectangular in tangential view) differs from most material seen. Pith made up of thin-walled spongy tissue has been noted for Bombacoideae (Metcalfe \& Chalk 1950). Ochroma, with one accepted species (O.pyramidale (Cav. ex Lam.) Urb.), has affinities with Bombacaceae/Malvoideae (Duarte et al. 2011; Marinho et al. 2014). Some key wood-anatomical characters are shared with Bombacoideae, which have medium-large intervessel pits and include taxa with wide, sparsely distributed vessels and tile cells (rare in Malvoideae), but there are also differences (absence of storied parenchyma, Table 1). Long vessel tails and wide fibers, characters seen in the fossil, have also been noted as distinguishing Ochroma from Bombacaceae in New World taxa (Détienne et al. 1983). Ochroma pyramidale occurs in early successional lowland to montane wet tropical forests on rich soil, from southern Mexico and Central America into South America, and within the Amazon basin is more common on the western margins (Pennington et al. 2004; GBIF 2001-onwards).

No fossil wood shows a close correspondence to the fossil specimen and none to our knowledge has been described as having similarity to Ochroma.

Based on characters shared with Ochroma pyramidale, the fossil is named to a new species within the genus.

\section{Malvaceae - Byttneroideae}

GUAZUMA Mill.

Guazuma santacruzensis Woodcock, Meyer et Prado, sp.nov. (Fig. 4)

Diagnosis: Growth rings absent or indistinct, wood diffuse porous. Vessels solitary in and short radial multiples, mean tangential diameter 50-100 $\mu \mathrm{m}$, perforations simple, intervascular pits alternate. Fibers non-septate. Rays semi-storied, 1-8-seriate, composed of procumbent body ray cells and tile cells of the Intermediate type. Axial parenchyma, fibers, and vessel elements storied.

Etymology: The species epithet refers to the province of Santa Cruz, which includes the district of Sexi and the fossil forest.

Holotype: USM-S8 (est. diameter $7.5 \mathrm{~cm}$ ).

Type locality: Piedra Chamana Fossil Forest main site, associated with the volcanic flow deposits.

Description: Growth rings absent or indistinct. Wood diffuse porous (Fig. 4A). Vessels solitary and in multiples of 2-5, tangential diameter $98 \pm 19 \mu \mathrm{m}$, frequency 


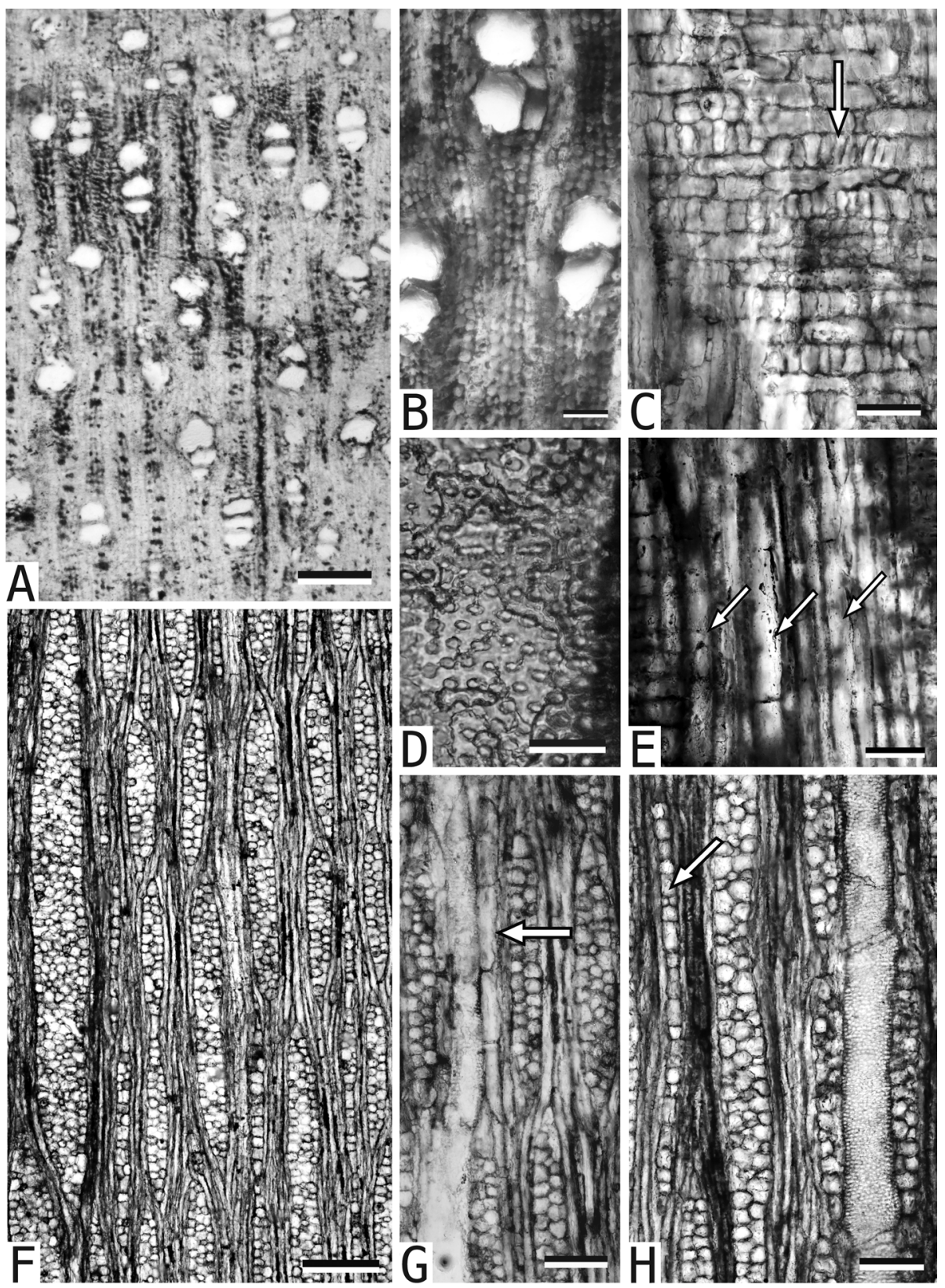

Figure 4. Guazuma santacruzensis Woodcock, Meyer et Prado, sp. nov. USM-S8. - A: Diffuseporous wood, TS. - B: Very thin-walled fibers, TS. - C: Intermediate type tile cells, broadly to narrowly rectangular (arrow), RLS. - D: Intervessel pits alternate, oval-shaped, TLS. E: Apotracheal parenchyma (arrows) alternating with fibers, RLS. - F: Low rays storied, TLS G: Axial parenchyma in strands of 4 (arrow), TLS. - H: Uniseriate ray (arrow), TLS. - Scale bars $=250 \mu \mathrm{m}$ in $\mathrm{A} ; 200 \mu \mathrm{m}$ in $\mathrm{F} ; 100 \mu \mathrm{m}$ in $\mathrm{G}, \mathrm{H} ; 50 \mu \mathrm{m}$ in $\mathrm{C}, \mathrm{E} ; 40 \mu \mathrm{m}$ in $\mathrm{B} ; 25 \mu \mathrm{m}$ in $\mathrm{D}$. 
$\sim 18 / \mathrm{mm}^{2}$, in outline round to somewhat elongate tangentially (but not appearing crushed), end walls oblique, perforations simple; intervessel pits alternate, oval with elongate apertures (Fig. 4D), 5-7 $\mu \mathrm{m}$; vessel-ray parenchyma pits not observed; vessel element length $454 \pm 30 \mu \mathrm{m}$. Fibers non-septate, very thin-walled, approximating axial parenchyma in width (not extremely narrow) (Fig. 4B), with minutely bordered pits in radial walls. Axial parenchyma scanty paratracheal, sparse; apotracheal parenchyma (sparsely?) diffuse to diffuse-in-aggregates (Fig. 4E), not clearly observed in transverse section, in strands of (3) 4 (5) cells (Fig. 4G). Rays 1-8-seriate; narrow rays uniseriate with occasional biseriate portions (Fig. 4H), low (1-2 cells high) to high, composed of mixed procumbent and erect cells very similar in morphology to the procumbent and tile cells of the wider rays (Fig. $4 \mathrm{H}$ ); multiseriate rays with tile cells somewhat to $2 \times$ higher than procumbent cells (Intermediate type), broadly to narrowly rectangular in radial section (Fig. 4C); rays generally lacking marginal cells that are distinct morphologically from the body ray cells, occasionally with uniseriate extensions of $4-6$ cells; low rays $426 \pm 68 \mu \mathrm{m}$, high rays $1512 \pm 415 \mu \mathrm{m}$, frequency $\sim 7 /$ tangential $\mathrm{mm}$. Rays often fused vertically. Low rays storied to irregularly storied (Fig. 4F); axial parenchyma, fibers, and vessel elements storied; 3.5 tiers $/ \mathrm{mm}$.

Affinity. In the InsideWood database, the combination of diffuse porous wood, small intervessel pits; rays 4-10-seriate, $>1 \mathrm{~mm}$, with tile cells, and lacking sheath cells; and low rays storied (IAWA characters 5, 25, 98, 102, 111, 119 with 110 absent) occurs only in Malvaceae - in Byttnerioideae (Guazuma) and Grewioideae (Grewia, Luehea, Microcos). These subfamilies are considered sister groups (Alverson et al. 1999). Guazuma, particularly G. ulmifolia Lamb., is most similar to the fossil, sharing most coded characters and additionally having Intermediate type tile cells, uniseriate rays infrequent and anatomically similar to wider rays, and rays generally without distinct marginal cells; however, G. ulmifolia has crystals not seen in the fossil. Guazuma is a New World genus with three species occurring in early successional dry to mesic and seasonally flooded forests (Gentry 1993; Kubitzki 1989). Other similar taxa in Grewioideae (Luehea) differ in having rays frequently uniseriate and with marginal cells.

Of the fossil woods referred to Malvaceae, Guazumaoxylon Rodríguez-Reyes, Falcon-Lang, Gasson, Collinson \& Jaramillo, with type species G. miocenica from the Miocene of Mexico, has Intermediate-type tile cells but differs from the fossil in having smaller pits, aliform paratracheal parenchyma, and rays that are narrower and non-storied.

Based on similarity to the Neotropical genus Guazuma, particularly G. ulmifolia, the fossil is named to a new species within this genus.

\section{Malvaceae - Grewioideae}

\section{GreWIA L.}

Grewia americana Woodcock, Meyer et Prado, sp. nov. (Fig. 5)

Diagnosis: Wood with distinct growth rings, diffuse to semi-ring porous. Vessels solitary and in short to long radial multiples, perforations simple, mean tangential diameter 50-100 $\mu \mathrm{m}$, intervessel pits alternate, vessel-ray parenchyma pits similar to intervessel pits. Fibers non-septate. Axial parenchyma scanty paratracheal. Rays stor- 


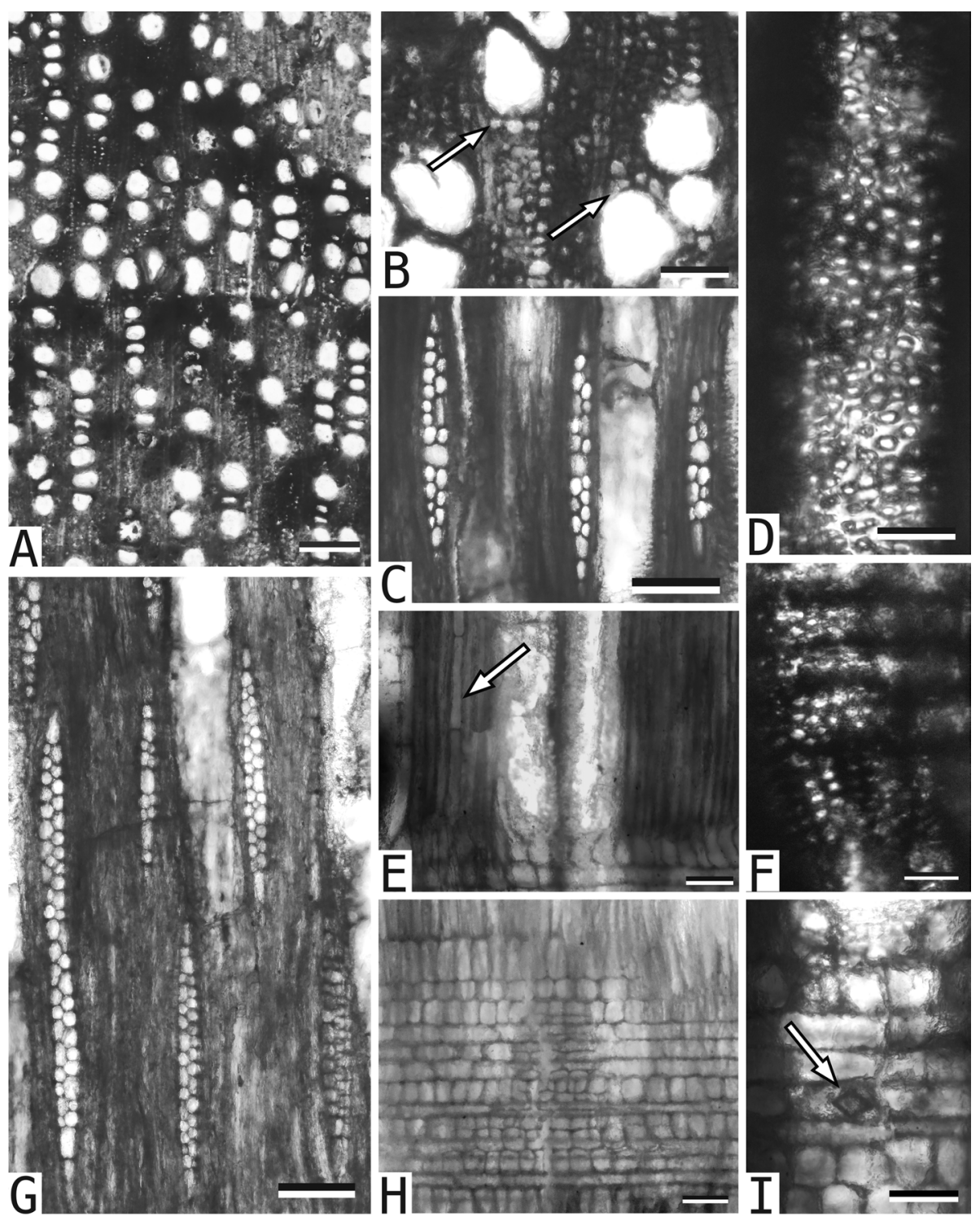

Figure 5. Grewia americana Woodcock, Meyer et Prado, sp. nov. USM-S159. - A: Wood diffuse to semi-ring porous, vessels in short to long radial multiples, TS. - B: Scanty paratracheal parenchyma (arrows), TS. - C: Biseriate rays with tile cells, TLS. - D: Intervessel pits alternate, TLS. - E: Apotracheal parenchyma strand (arrow), RLS. - F: Vessel-ray parenchyma pits similar to intervessel pits, RLS. - G: Low rays storied, RLS. - H: Ray with tile cells and marginal cells, RLS. - I: Prismatic crystal in ray cell (arrow), RLS. - Scale bars $=200 \mu \mathrm{m}$ in A; $100 \mu \mathrm{m}$ in G; $50 \mu \mathrm{m}$ in $\mathrm{C}, \mathrm{E}, \mathrm{H} ; 40 \mu \mathrm{m}$ in $\mathrm{B}, \mathrm{I} ; 20 \mu \mathrm{m}$ in $\mathrm{D}, \mathrm{F}$. 
ied, mostly biseriate, composed of procumbent cells and Intermediate type tile cells, with 1-2 rows of upright cells at the margins. Prismatic crystals in ray cells.

Etymology: This wood is named after its New World occurrence.

Holotype: USM-S159 (diameter $4 \mathrm{~cm}$ ).

Type locality: Piedra Chamana Fossil Forest main site, associated with the volcanic flow deposits.

Description: Growth rings distinct, marked by an incomplete ring of solitary vessels, changes in fiber wall thickness, and discontinuous marginal parenchyma. Wood diffuse to semi-ring porous (Fig. 5A). Vessels solitary and in radial multiples of 2-3, occasionally 4-7 (Fig. 5A), especially in the later part of the growth ring; tangential diameter $73 \pm 14 \mu \mathrm{m}$, frequency $\sim 52 / \mathrm{mm}^{2}$, round in outline, end walls horizontal to slightly oblique with long tails, perforations simple; intervessel pits alternate, round to oval (Fig. 5D), with apertures elongate radially to coalescent, $\sim 5-7.5 \mu \mathrm{m}$; vessel ray pits bordered, similar to intervessel pits (Fig. 5F); vessel element length $367 \pm 41$ $\mu \mathrm{m}$. Fibers non-septate, thin- to thick-walled. Axial parenchyma scanty paratracheal (Fig. 5B); apotracheal parenchyma scarce, in occasional diffuse strands (Fig. 5E) and occurring irregularly at the growth ring boundary; in strands of 4 cells. Rays 2(-3)-seriate, composed of procumbent and square to upright tile cells that are mostly 1.5 to 2 (3) times higher than the procumbent cells (Intermediate type) and broadly rectangular in radial view (Fig. 5H), with 1 (2) row(s) of high to very high upright cells at the margins; low rays often with tile cells extending across the width of ray (Fig. 5C); tangential diameter of procumbent ray cells $10-15 \mu \mathrm{m}$; rays of two distinct heights, low rays $321 \pm 58 \mu \mathrm{m}$, high rays $653 \pm 82 \mu \mathrm{m}$; ray frequency $\sim 6 /$ tangential $\mathrm{mm}$. Rays and vessel elements storied (Fig. 5G), 3 tiers/mm. Dark contents in vessels. Prismatic crystals occasional in procumbent ray cells (Fig. $5 \mathrm{I}$ ).

Affinity. The combination of vessel multiples $>4$ common (even if variable) and rays $1-3$-seriate and with tile cells (IAWA characters 10,97, 111 present with 98 and 99 absent) does not occur in any wood included in the IAWA database. Tile cells are a strong indication of Malvaceae, but this wood has several features unusual for the family. Most Malvaceous woods have axial parenchyma that is diffuse to diffuse-in-aggregates or, less commonly, in wider bands. Apotracheal parenchyma absent to sparse (apart from marginal parenchyma) is less prevalent but common in Grewioideae (InsideWood 2004-onwards). Ring/semi-ring porosity and vessels commonly in multiples of 4 or more and $>40 / \mathrm{mm}^{2}$ are likewise infrequent in the family (Table 1), recorded in 42 , 16, and 24, respectively, of the 341 species of Malvaceae included in the InsideWood database. The fossil displays many similarities to Grewia. This large ( $>300$ accepted species) genus of lianas, shrubs, and generally small trees occurs in dry areas and is distributed widely in the tropics except for the New World. Grewia is variable with respect to storying, axial parenchyma, and ray characteristics; shows a tendency toward ring- or semi-ring porosity; and is the only genus in the subfamily including species with vessel frequency $>40 / \mathrm{mm}^{2}$. Other features seen in the fossil also present in species of Grewia include diffuse or diffuse-in-aggregates apotracheal parenchyma absent (InsideWood 2004-onwards), vessels commonly in radial multiples of four or more (G. barombiensis K. Schum., InsideWood; G. multiflora Juss. H-19679 - Aw), narrow 
rays with tile cells extending the width of the ray ( $G$. androyensis Capuron - InsideWood; G. asiatica L., H-24275. and G. tiliaefolia Vahl, H-8347- Aw ), and rays 1-3-seriate and with tile cells ( $G$. androyensis Capuron, G. polygama Roxb., G. thouvenontii Danguy, G. villosa Willd. - InsideWood 2004-onwards) - the latter an unusual combination in Malvaceae. Tile cells in Grewia range from Intermediate to Pterospermum type and are broadly to narrowly rectangular (InsideWood 2004-onwards, Aw). Most species in the InsideWood database also have low rays and lack rays $>1 \mathrm{~mm}$.

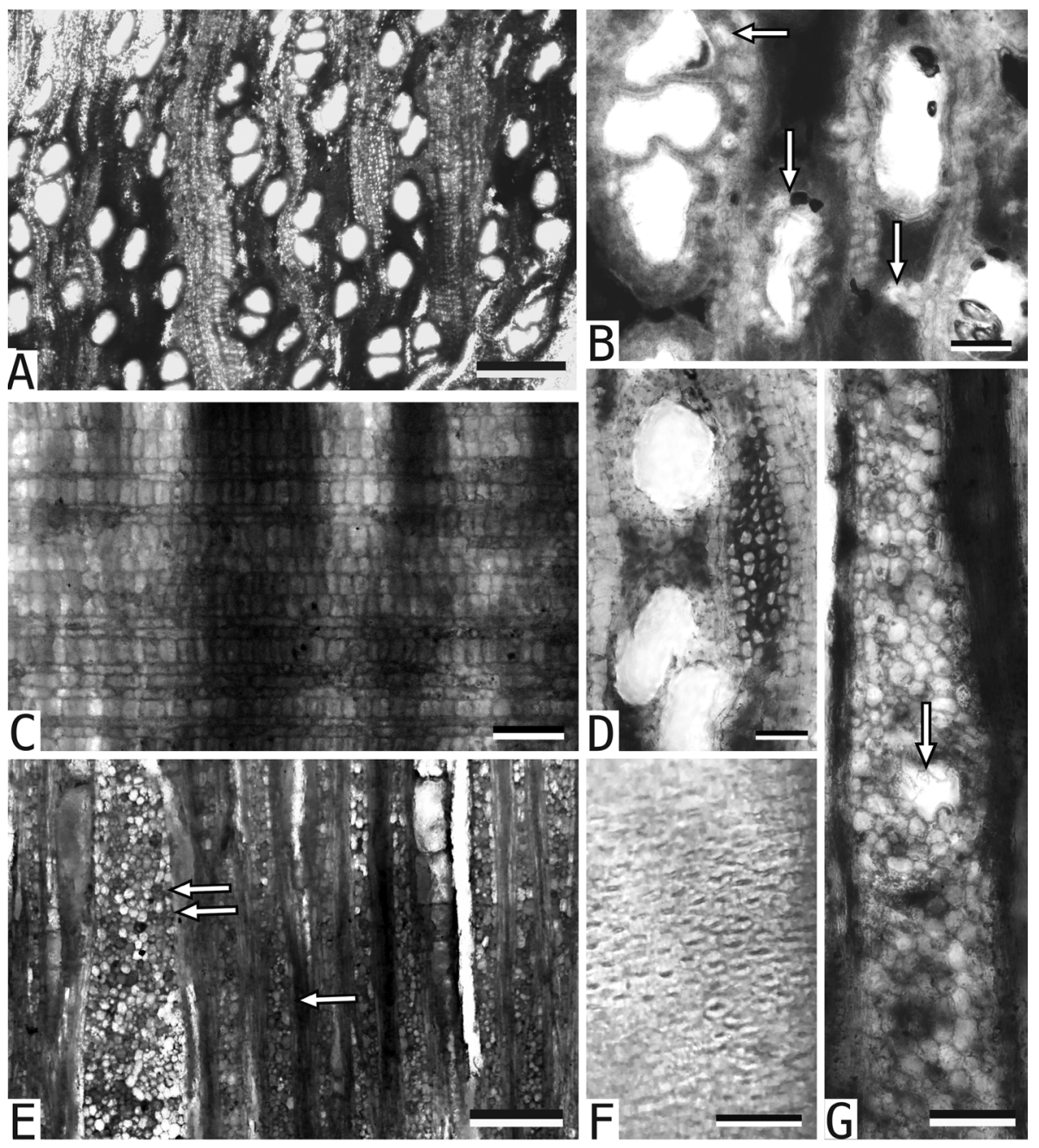

Figure 6. Grewinium canalisum. USM-S103. - A: Vessels solitary and in short radial multiples, TS. - B: Axial parenchyma scanty paratracheal, vasicentric, aliform (arrows), TS. - C: Ray with tile cells, RLS. - D: Fibers thin- to very thin-walled, TS. - E: Rays of two different sizes (narrow ray: single arrow, wide ray: double arrow), RLS. - F: Crowded alternate intervessel pits, TLS. - G: Radial canal (arrow), TLS. - Scale bars $=250 \mu \mathrm{m}$ in A, E; $100 \mu \mathrm{m}$ in C, G; $50 \mu \mathrm{m}$ in $\mathrm{B}, \mathrm{D} ; 20 \mu \mathrm{m}$ in $\mathrm{F}$. 
The fossil wood Grewinium (Bande \& Srivastava) Srivastava \& Guleria, with type species Grewinium intertrappeum (Shallom) Srivastava \& Guleria from the Deccan traps, was established for woods with similarity to Grewia. The fossil shows some correspondence to the genus but has narrow, storied rays. Woods, mainly from South Central Asia but also the Neogene of Europe, referred to Grewinium (Gregory et al. 2009), have tile cells and rays that are generally wide (4-10-seriate) and >1 mm high but vary in presence of growth rings and marginal parenchyma, porosity, pit size, presence/type of axial parenchyma, presence of crystals, storying, and presence of radial canals (G. canalisum, InsideWood 2004-onwards). The fossil appears atypical relative to these woods in having vessels commonly in radial multiples $\geq 4$ and $40-100 / \mathrm{mm}^{2}$ and narrow rays that are storied and not $>1 \mathrm{~mm}$.

The fossil has features that are best encompassed within the variability seen in modern Grewia species and is named to a new species in this genus.

GREWINIUM (Bande \& Srivastava) Srivastava \& Guleria 2000

Synonym: Grewioxylon Shallom non Schuster

Grewinium canalisum (Bande \& Srivastava) Srivastava \& Guleria 2000 (Fig. 6)

Synonym: Grewioxylon canalisum Bande \& Srivastava 1995

Specimen: USM-S103 (diameter $10 \mathrm{~cm}$ ).

Description: Growth rings absent/indistinct. Wood diffuse porous. Vessels solitary and in radial multiples of 2-3 (4) (Fig. 6 A), tangential diameter $78 \pm 17 \mu \mathrm{m}$, frequency $\sim 45 / \mathrm{mm}^{2}$, with occasional long tails, intervessel pits crowded alternate, polygonal (Fig. 6F), 5-7 $\mu \mathrm{m}$; vessel-ray parenchyma pits not observed, vessel element length $207 \pm 79 \mu \mathrm{m}$. Fibers very thin- to thin-walled (Fig. 6D). Axial parenchyma sparse to irregularly scanty paratracheal, vasicentric or with short wings (Fig. 6B), in wide strands 4(+?) cells long. Rays 1-15(+)-seriate (Fig. 6E), composed of procumbent body ray cells, tile cells $2-3 \times$ the height of the procumbent cells (Pterospermum type) and broadly rectangular in radial view (Fig. 6C), and 1-3 rows of upright to square marginal cells; rays of two distinct sizes, low rays $363 \pm 209 \mathrm{~mm}$ high, high rays $>2 \mathrm{~mm}$ high, frequency $\sim 8 /$ tangential $\mathrm{mm}$. Radial canals present in larger rays (Fig. 6G), one to two per ray.

Affinity. Tile cells establish the affinity of the fossil with Malvaceae, although radial canals are rare in this family. The only genus with this combination of characters in the InsideWood database is Luehea (Malvaceae - Grewioideae), but this New World genus and related genera (Microcos subclade of Grewioideae) differ from the fossil in having prevalent uniseriate rays and rays that are narrower and with some degree of storying. Apeiba (also Grewioideae) has also been noted as having radial canals (Wheeler et al. 2017).

The fossil wood Grewinium (Grewioxylon) canalisum (Bande \& Srivastava) Srivastava \& Guleria (reviewed/rephotographed in Wheeler et al.2017) from the Deccan Traps of India has Pterospermum type tile cells and radial canals and is similar to the fossil specimen in most respects, although having wider vessels; it is the only species referred to the genus that has radial canals. The Deccan fossils date from the latest 


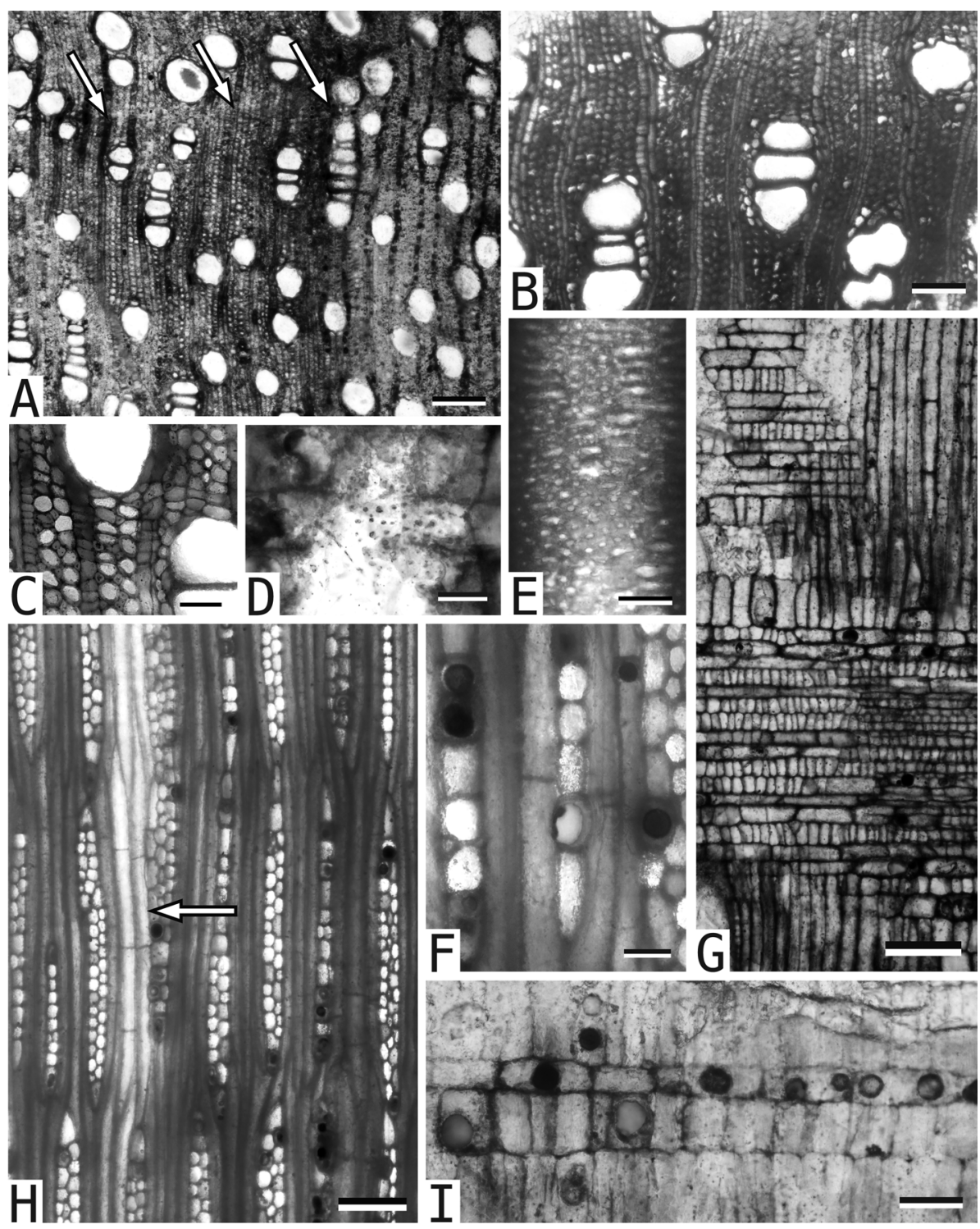

Figure 7. Luehea stratificata Woodcock, Meyer et Prado, sp. nov. USM-S120. - A: Diffuse- to semi-ring-porous wood, vessels solitary and in short to long radial multiples, growth ring boundary (arrows), TS. - B: Parenchyma scanty paratracheal and sparsely diffuse to diffuse-in-aggregates, TS. - C: Very thin-walled fibers, TS. - D: Vessel-ray parenchyma pits similar to intervessel pits, RLS.-E: Alternate intervessel pits, TLS. -F: Ray parenchyma with globules, TLS.-G: Ray with narrowly rectangular tile cells and one row of marginal cells, RLS. - H: Rays, axial parenchyma, fibers storied; axial parenchyma in strands of 4 (arrow), TLS. - I: Globules in ray parenchyma, RLS. - Scale bars $=200$ in A; $100 \mu \mathrm{m}$ in B, G, H; $50 \mu \mathrm{m}$ in C, I; $25 \mu \mathrm{m}$ in D, E, F. 
Cretaceous - early Paleogene, when the Indian subcontinent had not yet rafted out of the Southern Hemisphere. Wheeler et al. (2017) consider G. canalisum to have a clear affinity with Grewioideae. Supporting this placement are the generally sparse apotracheal parenchyma and aliform-winged paratracheal parenchyma and vessel frequency $>40 / \mathrm{mm}^{2}$ seen in the Peru fossil; these features are rare in Malvaceae but occur in some Grewioideae (Grewia, Mollia).

In consideration of the close similarity to the fossil wood Grewinium canalisum, we refer the fossil to this taxon. Establishment of a new genus for fossil woods with tile cells and radial canals, as mentioned by Wheeler et al. (2017), appears warranted, especially considering the absence of radial canals in modern Grewia species.

\section{LUEHEA Willd.}

Luehea stratificata Woodcock, Meyer et Prado, sp.nov. (Fig. 7)

Diagnosis: Growth rings distinct, wood diffuse to semi-ring porous. Vessels solitary and in short to long radial multiples, mean tangential diameter 100-150 $\mu \mathrm{m}$, perforations simple, intervessel pits alternate, vessel-ray parenchyma pits similar to intervessel pits. Fibers non-septate. Axial parenchyma scanty paratracheal and sparsely diffuse to diffuse-in-aggregates. Rays storied, 1-2-seriate, wider rays with procumbent body ray cells, tile cells of the Intermediate type and narrowly rectangular, and one row of marginal square to upright cells.

Etymology: The species epithet refers to the highly storied wood.

Holotype: USM-S120 (diameter $18 \mathrm{~cm}$ ).

Type locality: Piedra Chamana Fossil Forest main site, Sexi, Peru, associated with the volcanic flow deposits.

Description: Growth rings distinct, marked by tangentially flattened fibers and changes in vessel diameter and frequency. Wood diffuse to semi-ring porous (Fig. 7A). Vessels mainly solitary but also in radial multiples of 2-6 (7-8) (Fig. 7A) and occasional irregular clusters, tangential diameter $132 \pm 24 \mu \mathrm{m}$, frequency $\sim 17 / \mathrm{mm}^{2}$, vessels round in outline, end walls oblique, perforations simple; intervessel pits alternate (Fig. 7E), 6-9 $\mu \mathrm{m}$; vessel-ray parenchyma pits bordered, similar to intervessel pits (Fig. 7D); vessel element length $467 \pm 40 \mu \mathrm{m}$. Fibers non-septate, very thin- to medium/thickwalled (Fig.7C); pitting not observed. Axial parenchyma scanty paratracheal and very sparsely diffuse to diffuse-in-aggregates (Fig. 7B), in strands of 4 cells (Fig. 7 H) or occasionally longer (paratracheal strands). Rays 1-2(-3-4)-seriate (Fig. 7H); uniseriate rays frequent, with occasional biseriate portions, composed of all procumbent or mixed procumbent and upright cells, 1-2 cells high to as high as highest multiseriate rays; wider rays composed of procumbent cells, tile cells approximately as high as the procumbent cells to slightly higher (Intermediate type) and narrowly rectangular in radial view (Fig. $7 \mathrm{G}$ ), and generally one row of marginal upright to square cells, often with long uniseriate extensions; low rays $426 \pm 57 \mu \mathrm{m}$; high rays $2-3 \times$ the height of the lower rays (986 $\pm 258 \mu \mathrm{m})$, often fused vertically by means of uniseriate extensions; ray frequency $\sim 10 /$ tangential $\mathrm{mm}$. All elements storied (Fig. $7 \mathrm{H}$ ), $\sim 2$ tiers per axial $\mathrm{mm}$. Frequent light to dark globules in ray parenchyma, resembling oil globules, one or sometimes two per cell (Fig. 7F, I). 
Affinity. Presence of tile cells is a strong indication of affinity with Malvaceae. In the InsideWood database, intervessel pits small to medium only, and rays $>1 \mathrm{~mm}$ high with tile cells and some degree of storying (IAWA characters 25, 26, 102, and 111 with 118 or 119 also present) occurs only in the subfamily Grewioideae (Colona, Grewia, Luehea, Lueheopsis). The occurrence of sparse to absent axial parenchyma in this subfamily has already been noted. Luehea appears to be most similar to the fossil specimen. This genus is diffuse to semi-ring porous and variably storied, generally has uniseriate rays prevalent, and includes taxa with vessels in occasional long radial multiples (L. grandiflora Mart. \& Zucc. - Sonsin et al. 2014; L. divaricata Mart., L. candida (Moc. \& Sessé ex DC.) Mart., L. speciosa Willd. - Aw). Tile cells are of the Intermediate type and broadly to narrowly rectangular (cf. L. grandiflora, Sonsin et al. 2014, L. speciosa, InsideWood 2004-onwards) as in the fossil. One difference is that Luehea generally has wider rays and crystals. This genus (and others in the subfamily) generally has dark contents in rays and often also discrete dark globules/ oil bodies. Oil bodies, while not commonly seen in prepared plant material because of the solutions used, can often be found intact in fresh tissues (Lersten et al. 2006) - and possibly, as here, in permineralized material. Luehea (16 species) is a New World genus of deciduous to semi-deciduous / brevi-deciduous trees occurring in Central and South American seasonal to seasonally flooded forests (Gentry 1993; Wittmann et al. 2006). Grewia, although also showing a tendency toward ring or semi ring porosity and long vessel multiples, generally has rays $<1 \mathrm{~mm}$ and is less storied; tile cells appear to be Intermediate to Pterospermum type.

The fossil wood Tilioxylon lueheaformis Crawley (Crawley 2001), from the Pliocene of Britain, was named for its similarity to Luehea (formerly in Tiliaceae). Although sharing many characters with the fossil, including tile cells apparently of the Intermediate type and absence of elaborate paratracheal parenchyma, T. lueheaformis has vessels primarily in multiples and rays wider and non-storied. Crawley (2001) notes that this form genus (Tilioxylon Burgh) and Grewioxylon have been used for Malvaceous woods with vessels in long radial multiples, diffuse to diffuse-in-aggregates parenchyma, and rays with tile cells; however, the type species of Tilioxylon (T. palaeocordatum Burgh) has homocellular rays lacking tile cells (Crawley 2001).

The fossil is most similar to New World Luehea and related taxa within Grewioideae and is named to a species within this genus.

\section{VASIVAEA Baill.}

Vasivaea weigendii Woodcock, Meyer et Prado, sp. nov. (Fig. 8)

Diagnosis: Growth rings present, wood diffuse to semi-ring porous. Vessels solitary and in short radial multiples, mean tangential diameter 50-100 $\mu \mathrm{m}$, perforations simple, intervessel pits alternate, vessel-ray parenchyma pits similar to intervessel pits. Fibers non-septate. Axial parenchyma scanty paratracheal and diffuse to diffuse-in-aggregates . Rays non-storied, 1-4-seriate, composed of procumbent body ray cells, Intermediate type tile cells, and one row of marginal upright cells or with long uniseriate extensions. Vessel elements, fibers, and axial parenchyma irregularly storied. 


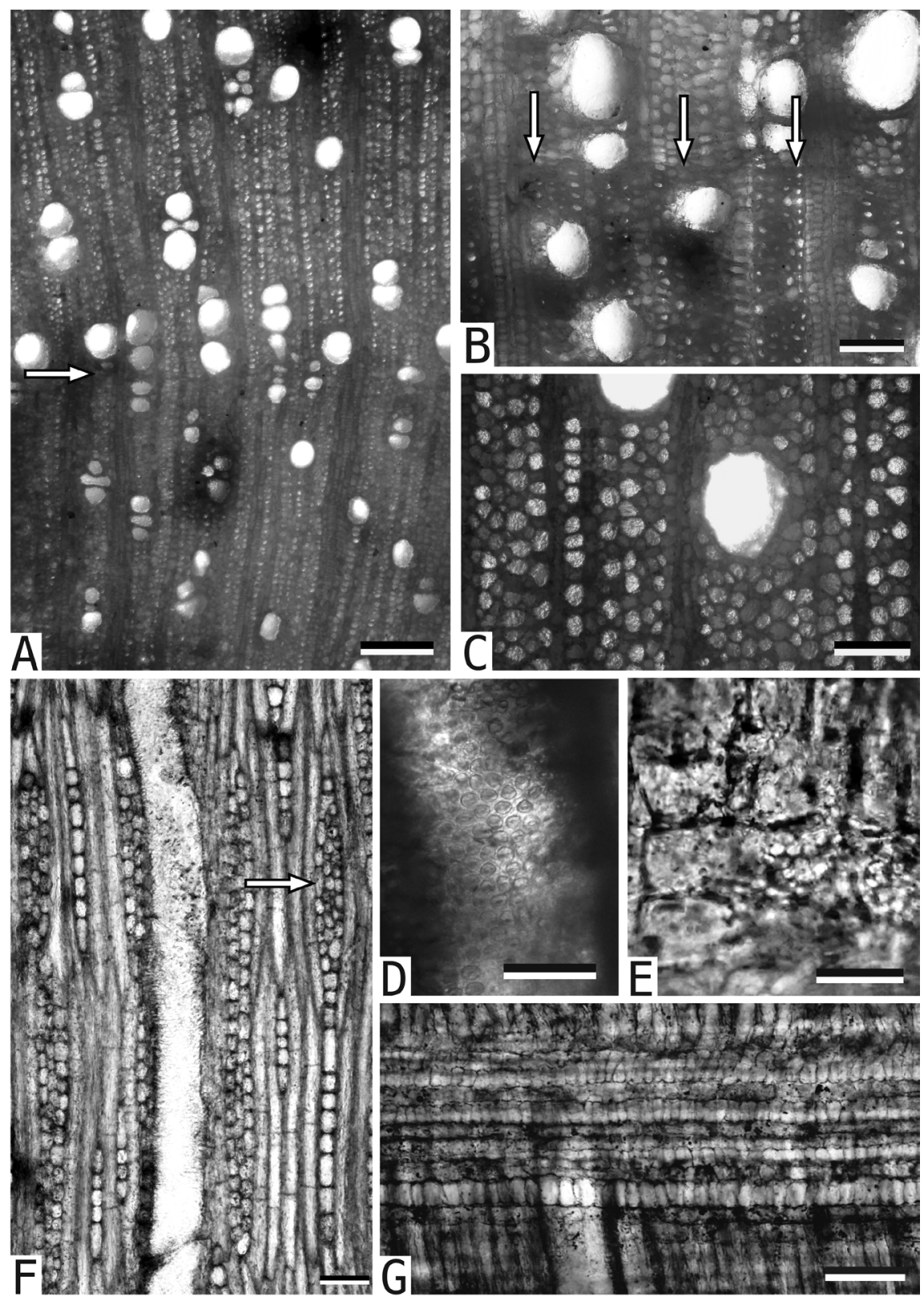

Figure 8. Vasivaea weigendii Woodcock, Meyer et Prado, sp. nov. USM-S176. - A: Vessels solitary and in short radial multiples, wood diffuse to semi-ring porous, growth ring boundary (arrow), TS. - B: Growth ring marked by changes in fiber wall thickness (arrows), TS. - C: Axial parenchyma diffuse to diffuse-in-aggregates, TS. - D: Alternate intervessel pits, TLS. - E: Vessel-ray parenchyma pits similar to intervessel pits, RLS. - F: Rays 1-4-seriate, fibers and axial parenchyma storied, sheath cells (arrow), TLS. - G: Ray with Intermediate type tile cells, RLS. - Scale bars $=250 \mu \mathrm{m}$ in A; $100 \mu \mathrm{m}$ in B, C; $75 \mu \mathrm{m}$ in F, G; $40 \mu \mathrm{m}$ in D, E. 
Etymology: The fossil is named for Maximilian Weigend, for his contributions to the floristics and ecology of northern Peru.

Holotype: USM-S176 (diameter $10 \mathrm{~cm}$ ).

Type locality: Piedra Chamana Fossil Forest main site, Sexi, Peru, associated with the volcanic flow deposits.

Description: Growth rings present, marked by radially flattened, thicker-walled fibers and changes in vessel diameter and arrangement (Fig. 8 A, B). Wood diffuse to semi-ring porous (Fig. 8 A). Vessels solitary, in radial multiples of 2-4, and in occasional irregular clusters, tangential diameter $86 \pm 19 \mu \mathrm{m}$, frequency $\sim 9 / \mathrm{mm}^{2}$, slightly oval to round in outline, end walls oblique, perforations simple; intervessel pits alternate, round to oval with slit-like apertures, 5-7.5 $\mu \mathrm{m}$ (Fig. 8D); vessel-ray parenchyma pits bordered, similar to intervessel pits (Fig. 8E); vessel element length $294 \pm 81 \mathrm{~mm}$. Fibers nonseptate, walls very thin to medium-thick, pitting not observed. Axial parenchyma scanty paratracheal and diffuse to diffuse-in-aggregates (Fig. 8C); uniseriate bands alternating with narrow fiber bands 2-3 cells wide (banding not very evident in transverse section), in strands (3-) 4 cells long. Rays $1-4(-5)$-seriate (Fig. 8F); uniseriate rays frequent, low (1 to 2 cells long) to high, composed of mixed procumbent and upright cells, with occasional biseriate portions; multiseriate rays composed of procumbent cells and tile cells that are approximately $1-1.5 \times$ as high as the procumbent cells (Intermediate type) and broadly to narrowly rectangular (Fig. $8 \mathrm{G}$ ), generally with one row of upright cells at the margins or with uniseriate extensions to 9 (14) cells long, also with occasional sheath cells higher than the tile and procumbent cells (Fig. 8F); rays sometimes joined by uniseriate extensions; height $384 \pm 141 \mathrm{~mm}$, frequency $\sim 8$ /tangential mm. Vessel elements, axial parenchyma, and fibers irregularly storied; 2-3 tiers per millimeter. Crystals not observed.

Affinity. In the InsideWood database, vessels 50-100 $\mu \mathrm{m}$, diffuse-in-aggregates parenchyma, axial parenchyma in strands of 4 , and rays not $>1 \mathrm{~mm}$ and with tile cells (IAWA characters 41, 77, 92, 111 with 90 and 102 absent) occurs only in Dombeyoideae (Dombeya) and Grewioideae (Grewia, Luehea, Vasivaea). Vasivaea appears to be most similar to the fossil. This genus has frequent low to high uniseriate rays, multiseriate rays with uniseriate extensions, abundant apotracheal parenchyma, and rays with tile and sheath cells (Uw30522, InsideWood 2004-onwards). Tile cells appear to be of the Intermediate type (although no radial section was available for reference). Other similar genera (Luehea, Grewia) lack the abundant apotracheal parenchyma seen in the fossil; Luehea also has rays $>1 \mathrm{~mm}$. Vasivaea is a New World genus with two species occurring in Amazonian and Colombian Inter-Andean riparian/seasonally flooded lowland forests (Pennington et al. 2004).

It appears that no fossil wood has been described showing a close correspondence to the fossil.

The fossil is most similar to extant Vasivaea (Grewioideae) and is named to a new species within this genus. 


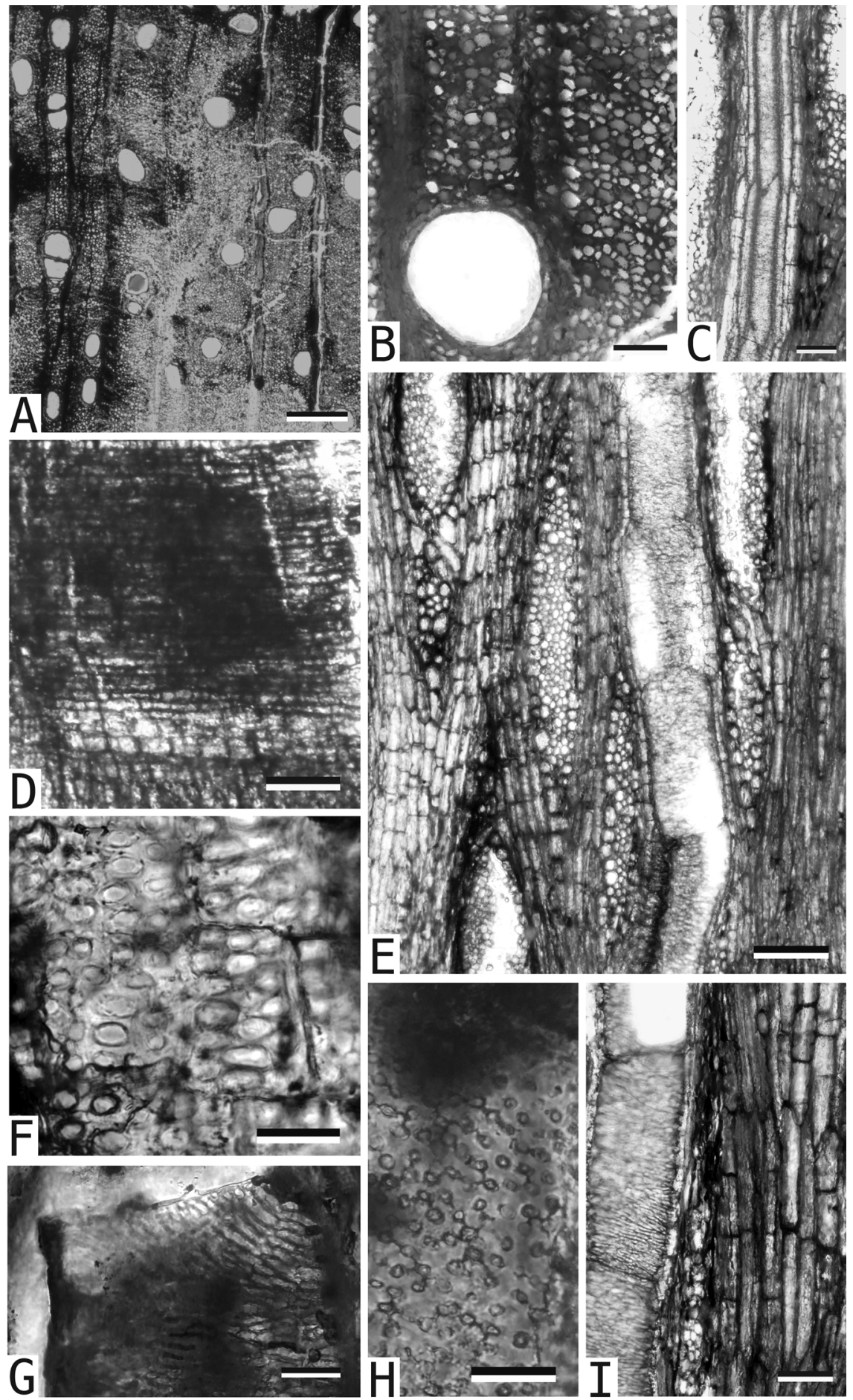




\section{Malvaceae - Sterculioideae}

\section{STERCULIA L.}

Sterculia matrum Woodcock, Meyer et Prado, sp. nov. (Fig. 9)

Diagnosis: Growth rings indistinct or absent, wood diffuse porous. Vessels solitary and in short radial multiples, mean tangential diameter 150-200 $\mu \mathrm{m}$, intervessel pits alternate, vessel-ray parenchyma pits similar to intervessel pits but somewhat larger or enlarged with reduced borders. Fibers non-septate. Axial parenchyma vasicentric and diffuse-in-aggregates. Rays non-storied, 1-12-seriate, composed of low procumbent body ray cells, sheath cells, and 2-4 marginal rows of square to upright or tall procumbent cells. Axial parenchyma and vasicentric tracheids storied.

Etymology: The specific epithet refers to the women of the Club de Madres, a civic organization in Sexi that has supported our scientific work.

Holotype: USM-S172 (diameter $9 \times 11 \mathrm{~cm}$ ).

Type locality: Piedra Chamana Fossil Forest main site, Sexi, Peru, associated with the volcanic flow deposits.

Description: Growth rings indistinct/absent. Wood diffuse porous (Fig. 9A). Vessels solitary and in groups of 2-3 (4), round to oval in outline, tangential diameter $177 \pm 46 \mu \mathrm{m}$, frequency $4 / \mathrm{mm}^{2}$, with wall sculpturing (Fig. 9G, I), perforations simple; intervessel pits alternate crowded (Fig. $9 \mathrm{H}$ ), $\sim 5 \mu \mathrm{m}$; vessel-axial parenchyma (and -ray parenchyma?) pits similar to intervessel pits, although somewhat larger, to enlarged with reduced borders, rounded to elongate, and 10-20 $\mu \mathrm{m}$ (Fig. 9F); vessel element length $405 \pm 58 \mu \mathrm{m}$. Vasicentric tracheids with distinctly bordered pits present, intermixed with paratracheal parenchyma strands and of similar dimensions (Fig. 9C). Fibers non-septate, very thin- to thick-walled, diameter $\sim 18 \mu \mathrm{m}$, pitting not observed. Axial parenchyma vasicentric, sheath mostly 1 cell wide, also diffuse-in-aggregates intermixed with 2-3-cell-wide bands of narrow fibers (Fig. 9B), in strands of 2-4 cells (Fig. 9I). Rays 1- to $\sim 12$-seriate (Fig. 9E), of two distinct sizes; 1(-2)-seriate rays primarily of square to upright and high procumbent cells, 2 cells to $>1 \mathrm{~mm}$ high; more commonly multiseriate, composed of low, radially elongate procumbent body ray cells, with mainly 2-4 marginal rows of square, upright, or high procumbent cells, and sheath cells (Fig. 9D, E), occasionally with long uniseriate extensions; height 1085 $\pm 500 \mu \mathrm{m}$, frequency $\sim 3 /$ tangential $\mathrm{mm}$. Rays often fused vertically. Axial parenchyma and vasicentric tracheids storied (Fig. 9E). Dark contents in vessels and ray cells.

Affinity. In the InsideWood database, vessel diameter 100-200 $\mu \mathrm{m}$; axial parenchyma diffuse-in-aggregates in strands $2-4$ cells long; larger rays $>10$-seriate, with sheath cells, and lacking tile cells; and axial parenchyma and/or vessel elements storied

Figure 9. Sterculia matrum Woodcock, Meyer et Prado, sp.nov. USM-S172. - A: Diffuse-porous wood, TS. - B: Vasicentric and diffuse-in-aggregates parenchyma, TS - C: Vasicentric tracheids, TLS. - D: Ray with margin of high procumbent cells, RLS. - E: Rays non-storied with sheath cells, vessel with parenchyma sheath,TLS.-F: Vessel-ray parenchyma pits enlarged with reduced borders, RLS. - G: Vessel with wall sculpturing, RLS. - H: Alternate intervessel pits, TLS. - I: Axial parenchyma in strands of 2-4 and storied, TLS. - Scale bars $=500 \mu \mathrm{m}$ in A; $200 \mu \mathrm{m}$ in $\mathrm{E} ; 150 \mu \mathrm{m}$ in $\mathrm{D} ; 100 \mu \mathrm{m}$ in $\mathrm{B}, \mathrm{C}, \mathrm{I} ; 40 \mu \mathrm{m}$ in $\mathrm{G} ; 25 \mu \mathrm{m}$ in $\mathrm{F}, \mathrm{H}$. 
(IAWA characters 42, 77, 91, 92, 99, 110, 120, with 111 absent) occurs only in Malvaceae - Sterculiaceae (Brachychiton, Heritiera, Hildegardia, and Sterculia). Rays that lack tile cells, are usually $>10$-seriate, and have body ray cells very small in dimension in tangential view appear to distinguish Sterculiaceae within Malvaceae (Table 1). In this subfamily, paratracheal parenchyma is generally vasicentric, isolating the vessels from the rays (Chattaway 1937). Vessel-axial parenchyma pits in Sterculioideae are typically bordered and similar to intervascular pits but if enlarged and corresponding to IAWA character 31 (some Sterculia, Brachychiton; Chattaway 1937; InsideWood 2004-onwards) generally have reduced borders. Vasicentric/vascular tracheids have not been recorded for Sterculioideae but occur sporadically in Malvaceae (InsideWood 2004-onwards). Sterculioideae is pantropical and includes two genera with New World representatives (Sterculia and Pterygota). Sterculia (S. apetala (Jacq.) H. Karst.) shares a large number of characters with the fossil and appears most similar. This pantropical genus of large lowland-forest canopy trees (c. 90 species worldwide, 40 species in the New World; GBIF 2001-onwards), occurring especially on good soil (Gentry 1993), is variable with respect to storying, axial parenchyma pattern (diffuse-in aggregates to widely banded, also variably aliform-confluent), and vessel-axial parenchyma pitting. The occurrence of wall sculpturing has been noted (Metcalfe \& Chalk 1950). Chattaway (1937) recognized two groupings within the genus. New World taxa $(S$. apetala, S. caribaea R.Br., S. colombiana Sprague, S. mexicana R.Br., S. recordiana Standl.; Aw) fall into her Sterculia A group and have narrow parenchyma bands (diffusein-aggregates parenchyma), enlarged vessel-parenchyma pits, and axial parenchyma in strands of two to four that are narrowly tapering, all characters seen in the fossil.

Among fossil woods, Sterculinium Guleria shares key features with the fossil (storied axial parenchyma, wide rays with sheath cells and lacking tile cells) but has widely banded parenchyma. The large number of woods referred to this genus, mostly from the Tertiary of Central South Asia, include S. shapurensis (Bande \& Prakash) Guleria and S. deccanensis (Lakhanpal, Prakash \& Bande) Guleria, which have diffuse-inaggregates / narrowly banded parenchyma like the fossil but differ in having vessel-ray parenchyma pits similar to intervessel pits. The Sterculinium woods appear to show a general correspondence to Chattaway's Old World grouping within Sterculia, characterized by (mostly) widely banded parenchyma and ray-axial parenchyma pits similar to intervessel pits.

The fossil is most similar to New World Sterculia species with diffuse-in-aggregates parenchyma and ray-parenchyma pits variably enlarged/with reduced borders, and is named to a new species within the genus.

\section{Melastomataceae}

MiconioIDeA Woodcock, Meyer et Prado, gen. nov.

Miconioidea eocenica Woodcock, Meyer et Prado, sp.nov. (Fig. 10)

Diagnosis: Growth rings distinct to indistinct, wood diffuse porous. Vessels solitary and in short radial multiples, mean tangential diameter 50-100 $\mu \mathrm{m}$, intervessel and vessel-ray parenchyma pits bordered, alternate. Fibers mostly non-septate and with occasional septae, dimorphic with parenchyma-like fibers in irregular bands. Axial 
parenchyma scanty paratracheal. Rays uniseriate, rarely biseriate or with short biseriate portions, of all upright cells or including some procumbent and weakly procumbent cells.

Etymology: The genus name refers to similarity of the fossil to woods in the subfamily Miconieae of Melastomataceae. The species name refers to the age of the fossil assemblage.

Holotype: USM-S61 (diameter $6 \mathrm{~cm}$ ).

Type locality: Piedra Chamana Fossil Forest main site, Sexi, Peru, associated with the volcanic flow deposits.

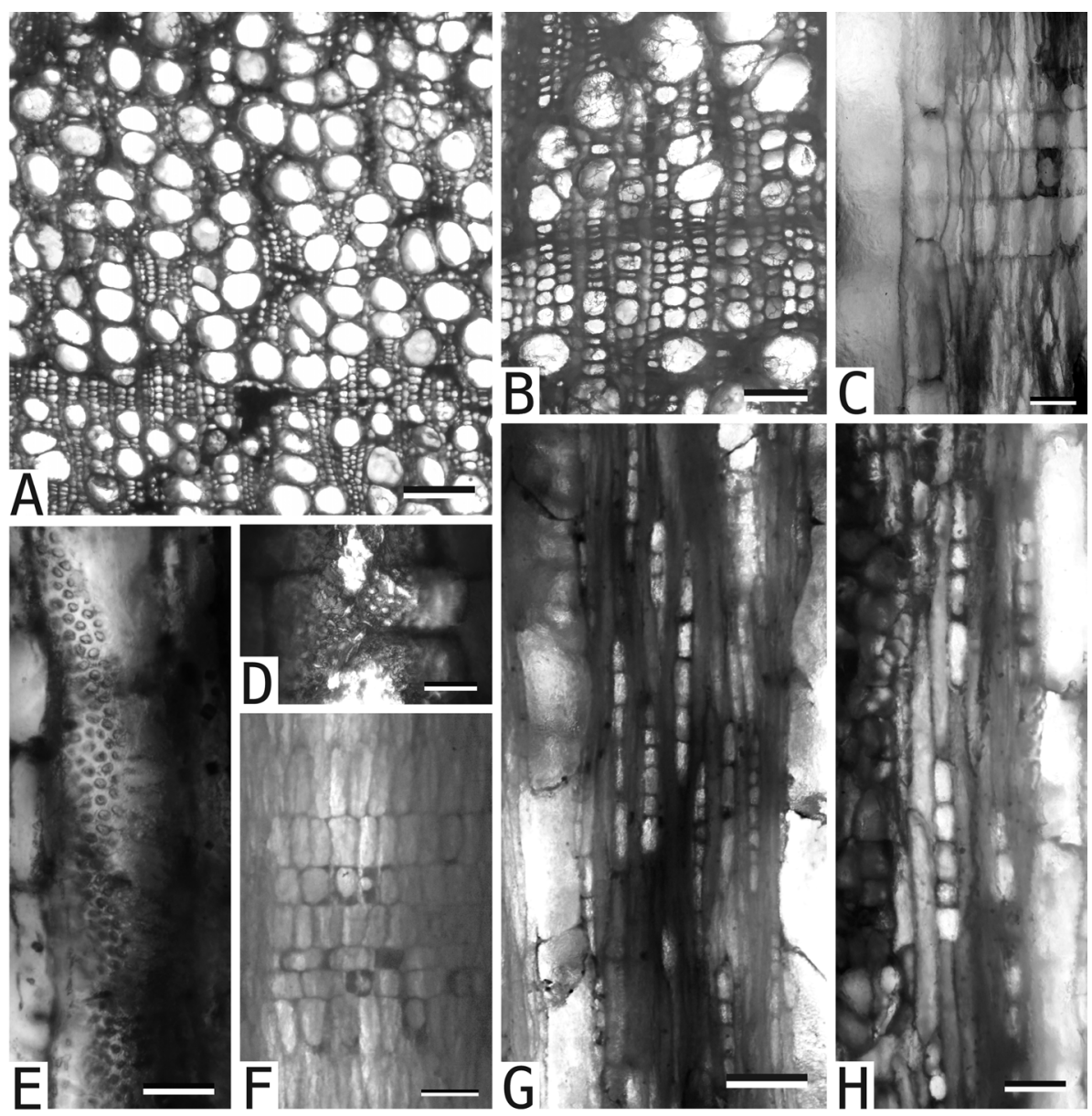

Figure 10. Miconioidea eocenica Woodcock, Meyer et Prado, gen. et sp. nov. USM-S61. A: Diffuse-porous wood with vessels in multiples, TS. - B: Parenchyma-like fiber band, TS. C: Homocellular ray composed of upright cells only, paratracheal parenchyma strand, RLS. - D: Vessel-ray parenchyma pits similar to intervessel pits, RLS. - E: Alternate intervessel pits, TLS. - F: Ray of upright and weakly procumbent cells, RLS. - G: Uniseriate rays, TLS. H: Short, parenchyma-like fibers, TLS. - Scale bars $=200 \mu \mathrm{m}$ in A; $100 \mu \mathrm{m}$ in B; $75 \mu \mathrm{m}$ in $\mathrm{F}, \mathrm{G}, \mathrm{H} ; 50 \mu \mathrm{m}$ in $\mathrm{C} ; 25 \mu \mathrm{m}$ in $\mathrm{D}, \mathrm{E}$. 
Description: Growth rings distinct to indistinct, marked by radially flattened fibers and changes in vessel frequency (Fig. 10A). Wood diffuse porous. Vessels crowded, solitary and in radial multiples of 2-4, also often in contact tangentially, with horizontal to oblique end walls, tangential diameter $81 \pm 19 \mu \mathrm{m}$, frequency $59 / \mathrm{mm}^{2}$, perforations simple; intervessel pits alternate, round to oval (Fig. 10E), $\sim 5 \mu \mathrm{m}$; vessel-ray parenchyma pits bordered, similar to intervessel pits (Fig. 10D); vessel element length $361 \pm 62 \mu \mathrm{m}$. Vessels with thin-walled tyloses (Fig. 10B). Fibers mostly non-septate, but some with thin septae, very thin- to thick-walled, dimorphic, consisting of narrow fibers and wider and shorter fibers that are parenchyma-like and occur diffusely and in irregular tangential bands (Fig. 10B,H); pitting not observed. Axial parenchyma scanty paratracheal, in strands of 4 or more cells long with tapered ends. Rays uniseriate (Fig. $10 \mathrm{G}$ ), rarely biseriate or with short biseriate portions, 1-2 to 20 cells high, of all upright cells or with occasional rows of procumbent to weakly procumbent cells occurring away from the margins (Fig. 10 C, F), height $261 \pm 95 \mu \mathrm{m}$, frequency $\sim 8$ / tangential $\mathrm{mm}$. Vessels occasionally with light-colored contents; ray parenchyma with dark contents at the cell periphery.

Affinity. Simple perforation plates; vessels $50-100 \mu \mathrm{m}$ and $40-100 / \mathrm{mm}^{2}$; vessel element length 350-800 $\mu \mathrm{m}$; and rays exclusively uniseriate, of upright and square cells, and 4-12/mm (IAWA characters 13, 41, 49, 53, 96, 105, and 115 with 97 and 106-108 absent) occurs only in Melastomataceae (Anerincleistus, Clidemia, Conostegia, Heterotrichum, Leandra, Miconia, Neblinathera). Vessels in radial multiples; dimorphic fibers; scanty paratracheal parenchyma; rays of erect, square, and weakly procumbent cells; and absence of crystals are characteristic of this family (Van Vliet \& Baas 1984), as is occurrence of both septate and non-septate fibers (ter Welle \& KoekNoorman 1981). The fossil shares the most characters with several taxa in Miconieae [Clidemia, Conostegia, Leandra, Llewlynia (now Henriettea), Tetrazigia]. This group typically has round to oval intervessel and vessel-ray parenchyma pits, uniseriate rays, and bands of parenchyma-like fibers (pseudoparenchyma) with variable proportions of axial parenchyma (ter Welle \& Koek-Noorman 1981; Van Vliet et al. 1981). While rays are generally high $(>1 \mathrm{~mm})$, several genera include taxa with lower rays (Tetrazigia, Charianthus). Tyloses occur in the tribe and also elsewhere in the family (InsideWood 2004-onwards). Miconieae is a largely New World tribe of shrubs and small trees that are mainly understory elements in tropical and subtropical forests. Several of the genera appearing most similar to the fossil are considered paraphyletic (Michelangeli et al. 2004), in addition to being quite large (Leandra, Clidemia, Conostegia with 200 species each, Miconia with $>1000$ species).

The only fossil wood referred to the Melastomataceae, Memecyloxylon germanicum Gottwald, differs from this specimen in having included phloem, much sparser vessels, and multiseriate rays (InsideWood 2004-onwards).

In the case of this specimen, comparisons to modern woods are constrained by the most similar modern taxa being highly diverse, in some cases questionably monophyletic, and including many shrubs and small trees typically not well represented in databases. Consequently, although correspondence to an extant taxon cannot be ruled out, the fossil is named to a new genus and species showing affinity to Melastomataceae - Miconieae. 


\section{Muntingiaceae}

\section{Muntingia L.}

Muntingia solipora Woodcock, Meyer et Prado, sp.nov. (Fig. 11)

Diagnosis: Wood with indistinct growth rings, diffuse porous. Vessels exclusively solitary, mean tangential diameter 150-200 $\mu \mathrm{m}$, perforations simple, vessel-ray parenchyma and vessel-tracheid pits alternate. Fibers non-septate. Axial parenchyma scanty paratracheal and diffuse-in-aggregates. Rays non-storied, 1-10-seriate, composed of procumbent cells and 1 or occasionally up to 4 rows of marginal cells. Vessel elements and axial parenchyma storied. Prismatic crystals in ray cells.

Etymology: The fossil is named after the predominantly solitary vessels seen in the wood.

Holotype: USM-S20 (est. diameter $18 \mathrm{~cm}$ ).

Type locality: Piedra Chamana Fossil Forest main site, Sexi, Peru, associated with the volcanic flow deposits.

Description: Growth rings indistinct/absent. Diffuse porous. Vessels exclusively solitary (Fig 11A), round in outline, end walls horizontal, tangential diameter $167 \pm 17$ $\mu \mathrm{m}$, frequency $\sim 6 / \mathrm{mm}^{2}$, perforations simple; vessel-ray parenchyma and vessel-tracheid pits bordered, crowded alternate (Fig. 11E), $4-5 \mu \mathrm{m}$; vessel element length $381 \pm 74 \mu \mathrm{m}$. Vasicentric tracheids present (Fig. 11G). Fibers non-septate, thin- to very thick-walled, with bordered pits $\sim 2-3 \mu \mathrm{m}$ in tangential and radial walls. Axial parenchyma scanty paratracheal and diffuse-in-aggregates in narrow bands 1 cell wide alternating with 1-3-cell-wide fiber bands (Fig. 11B), in strands mostly 2-4 cells long (Fig. 11C) but occasionally longer. Rays $1-10$-seriate (Fig. $11 \mathrm{~F}$ ); uniseriate rays $2-18$ cells high; multiseriate rays with body cells procumbent and one to occasionally 2-4 rows of upright or square marginal cells; procumbent cells at ray periphery slightly enlarged, occasionally elongate and more distinctly sheathing; height $2033 \pm 1202 \mu \mathrm{m}$, frequency $\sim 3$ /tangential $\mathrm{mm}$. Rays often fused vertically. Vessel elements and axial parenchyma storied (Fig. 11F). Prismatic crystals in upright and higher procumbent ray cells (Fig. 11D). Vessels with light to dark contents (Fig. 11B).

Affinity. In the InsideWood database, vessels solitary and 100-200 $\mu \mathrm{m}$ in diameter, axial parenchyma in strands of 2-4, and vessels and axial parenchyma storied (IAWA features 9, 42, 91, 92, 120) occurs only in Muntingia (Muntingiaceae). The specimen shares with this genus the characters of densely pitted vasicentric tracheids, uniseriate rays frequent, multiseriate rays with occasional sheath cells, rhomboidal crystals in ray cells, and vertically fused rays (Carlquist 2005); however, rays are high for the genus (Carlquist 2005; InsideWood 2004-onwards). The monotypic genus Muntingia (M. calabura L.) is a small evergreen tree distributed from Central America into the northern Andes and western Amazon basin as an element of secondary vegetation (Gentry 1993). The related genus Discraspidia differs from the fossil in several respects (narrower denser vessels, all multiseriate rays, non-storied wood; Carlquist 2005). Balanites (Zygophyllaceae) also shares many characters with the fossil but differs in having patterned vessel arrangement, axial parenchyma fusiform and in strands of 2, and wider rays (InsideWood 2004-onwards). 
No fossil wood displays the characters seen in the fossil specimen.

The closest affinity appears to be with Muntingia calabura and the fossil is named to a new species within this genus.
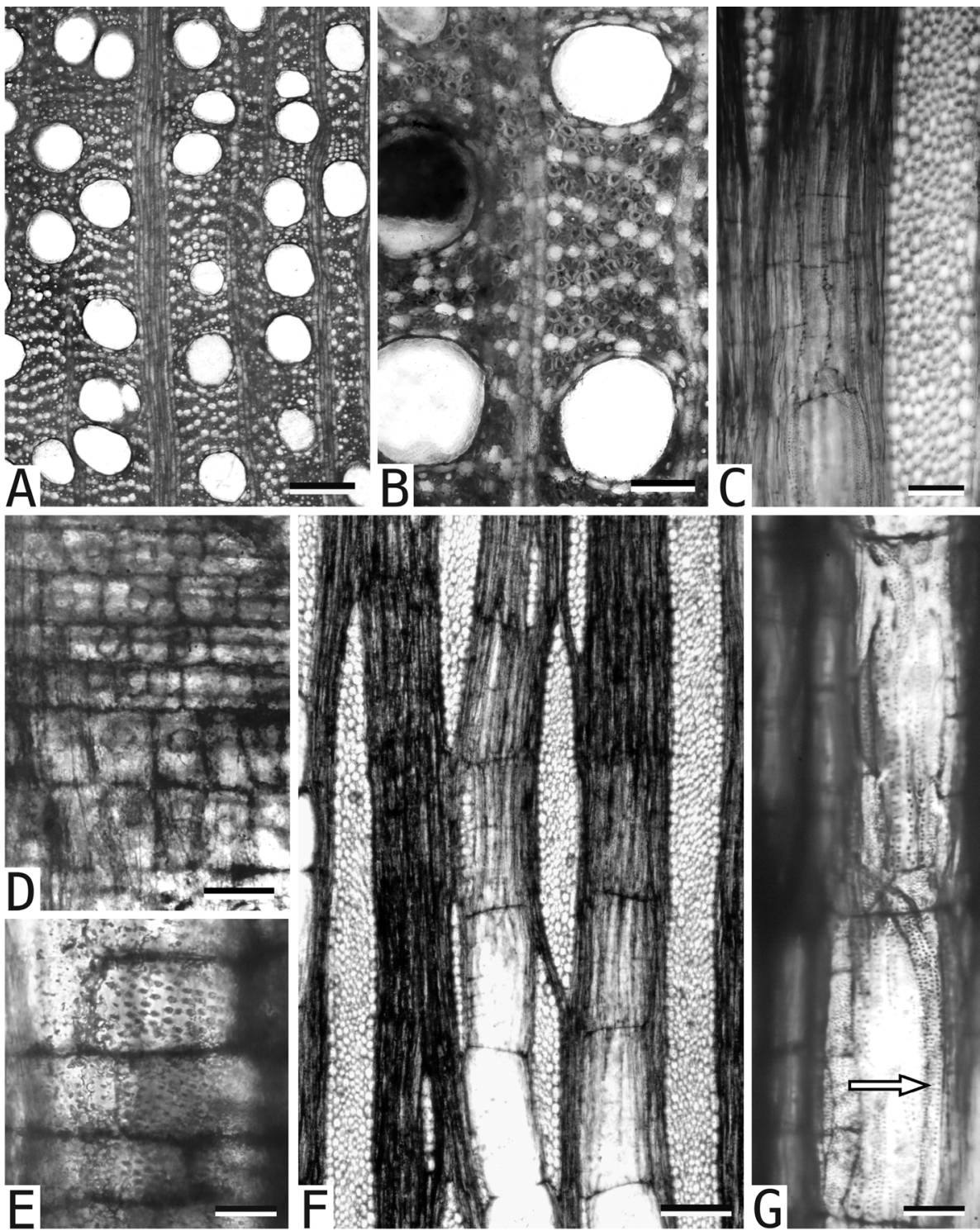

Figure 11. Muntingia solapora Woodcock, Meyer et Prado, sp. nov. USM-S20. - A: Solitary vessels, TS. - B: Diffuse-in-aggregates parenchyma, TS. - C: Axial parenchyma in strands of 4, TLS. - D: Crystals in ray parenchyma, RLS. - E: Vessel-ray parenchyma pits bordered, RLS. - F: Rays non-storied, 1-10-seriate; vessel elements and axial parenchyma storied, TLS.G: Vasicentric tracheid (arrow), RLS. - Scale bars $=250 \mu \mathrm{m}$ in A; $200 \mu \mathrm{m}$ in F; $100 \mu \mathrm{m}$ in $\mathrm{B}, \mathrm{C} ; 50 \mu \mathrm{m}$ in $\mathrm{D}, \mathrm{G} ; 25 \mu \mathrm{m}$ in $\mathrm{E}$. 


\section{Rubiaceae - Ixorioideae - Condamineeae}

\section{Calycophyllum DC.}

Calycophyllum plengei Woodcock, Meyer et Prado, sp. nov. (Fig. 12)

Diagnosis: Wood with distinct growth rings, diffuse porous. Vessels solitary and in short to long radial multiples, mean tangential diameter $\leq 50 \mu \mathrm{m}$, perforations simple, intervesssel pits alternate, vessel-ray parenchyma pits similar to intervessel pits. Rays 1-4-seriate; multiseriate rays composed of procumbent cells, 1-7 rows of upright to square marginal cells, and occasional sheath cells.

Etymology: The fossil is named for Heinz Plenge, photographer and conservationist.

Holotype: USM-S155 (est. minimum diameter $10 \mathrm{~cm}$ ).

Type locality: Piedra Chamana Fossil Forest main site, Sexi, Peru, associated with the volcanic flow deposits.

Description: Growth rings present, marked by changes in vessel frequency. Wood diffuse porous. Vessels solitary and in short to long (15-16-cells-long) radial multiples (Fig. 12A), round in outline, tangential diameter $42 \pm 8 \mu \mathrm{m}$, frequency $181 / \mathrm{mm}^{2}$, perforations simple, end walls oblique; intervessel pits alternate, oval with oval apertures (Fig. 12D), 4 $4 \mathrm{~m}$; vessel-ray parenchyma pits bordered, similar in size to intervessel pits but more crowded and circular to polygonal (Fig 12 E); vessel element length $317 \pm 82 \mu \mathrm{m}$. Fibers medium to very thick-walled (Fig. 12B), presence/absence of septae not determined. Axial parenchyma very sparse paratracheal, in strands $2-7$ cells long. Rays uniseriate and (2-)3(-4)-seriate (Fig 12F); uniseriate rays frequent, 2-10 cells high, made up of upright and/or tall procumbent cells; multiseriate rays with procumbent body cells and 1 to 6-7 rows of upright or square marginal cells (Fig. 12G), wider rays with occasional sheath cells; height $324 \pm 163 \mu \mathrm{m}$, frequency $\sim 5 /$ tangential $\mathrm{mm}$. Rays sometimes fused vertically through uniseriate extensions of upright cells. Circular perforations in enlarged upright ray cells (Fig. 12C).

Affinity. The combination of vessels commonly in radial multiples $\geq 4, \leq 50 \mu \mathrm{m}$ in diameter, and $\geq 100 / \mathrm{mm}^{2}$; very thick-walled fibers; and rays $1-4$-seriate with $>4$ rows of upright to square marginal cells (IAWA characters 10, 40, 50, 70, 98, 108) occurs only in Phyllanthaceae (Cleistanthus), Rubiaceae (Calycophyllum, Rondeletia) and Salicaceae (Casearia). The specimen shares the most characters with Calycophyllum, particularly $C$. candidissimum Vahl. Narrow, crowded vessels (although not to the extent seen in the fossil?), minute to small intervessel pits, vessel-ray parenchyma pits similar to intervessel pits, narrow rays with long uniseriate margins, sheath cells in wider ways, and absence of storying are typical of Rubiaceae; perforated ray cells are noted as widespread in the family (Jansen et al. 2002). Frequent uniseriate rays of all upright/square cells are also typical (InsideWood 2004-onwards). The fossil lacks rays $>1 \mathrm{~mm}$, a feature common in the family but not present in Calycophyllum (InsideWood 2004-onwards). Most features of the fossil are within the range of variability of Calycophyllum; perforated ray cells have been noted for C. candidissimum and other species in the genus (Chalk \& Chattaway 1933; León 2011; Baldin et al.2016). Similar taxa in Salicaceae (Casearia) and Phyllanthaceae (Cleistanthus) generally have rays $>1 \mathrm{~mm}$ (InsideWood 2004-onwards). 

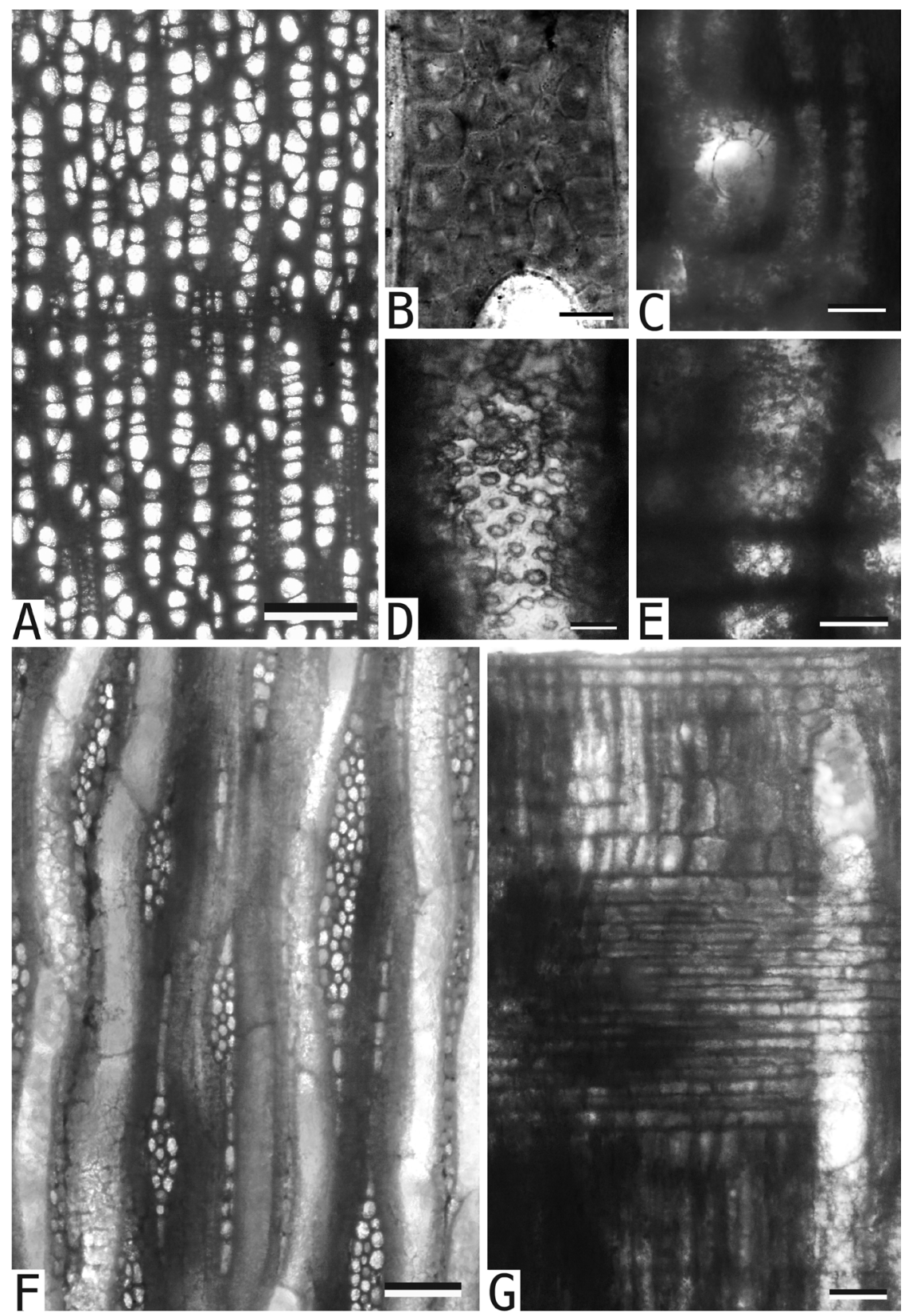

Figure 12. Calycophyllum plengei Woodcock, Meyer et Prado, sp. nov. USM-S155. - A: Diffuseporous wood with vessels in long radial multiples, TS. - B: Very thick-walled fibers, TS. C: Perforated ray cell, RLS. - D: Alternate intervessel pits, TLS. - E: Vessel-ray parenchyma pits similar to intervessel pits, RLS. - F: Multiseriate rays with long uniseriate extensions, TLS. G: Ray with marginal rows of square to upright cells, RLS. - Scale bars $=250 \mu \mathrm{m}$ in A; $100 \mu \mathrm{m}$ in F; $75 \mu \mathrm{m}$ in $\mathrm{G} ; 20 \mu \mathrm{m}$ in $\mathrm{B}, \mathrm{C}, \mathrm{E} ; 10 \mu \mathrm{m}$ in $\mathrm{D}$. 
Calycophyllum is a New World genus of 11 species of trees occurring in successional forests on alluvial soil, including flooded forests (C. spruceanum, Kubitzki 1989). The genus has vessels that are narrow and densely arranged relative to most tropical forest canopy trees. Calycophyllum species that are deciduous and occur in drier forests (C. candidissimum, C. multiflorum Griseb.) have vessels $<50 \mu \mathrm{m}$ in diameter and $>150 / \mathrm{mm}^{2}$, whereas evergreen $C$. spruceanum (Benth.) Hook.f. ex K. Sch., a taller tree occurring in Amazon lowland forests, has vessels 50-100 $\mu \mathrm{m}$ and 50-150/ $\mathrm{mm}^{2}$. The fossil is within the range of the deciduous taxa.

No fossil wood referred to Rubiaceae has the combination of narrow vessels in radial multiples $>4$ like the fossil and we are unaware of any wood described as having affinity with Calycophyllum.

The wood is named to a species of Calycophyllum based on its similarity to this genus, particularly C. candidissimum.

\section{Rutaceae - Amyridoideae}

\section{ZANTHOXYLUM L.}

Zanthoxylum reynelii Woodcock, Meyer et Prado, sp. nov. (Fig. 13)

Diagnosis: Wood with distinct growth rings, diffuse porous. Vessels solitary and in short radial multiples, mean tangential diameter 50-100 $\mu \mathrm{m}$; perforations simple; intervessel pits alternate, vessel-ray parenchyma pits similar to intervessel pits. Fibers non-septate. Parenchyma scanty paratracheal to vasicentric. Rays non-storied, 1-4-seriate, composed of procumbent cells and 1-6 rows of square to upright marginal cells. Rhomboidal crystals in rays.

Etymology: The fossil is named for Carlos Reynel, for his contributions to Neotropical botany.

Holotype: USM-S154 (diameter $7 \mathrm{~cm}$ ).

Type locality: Piedra Chamana Fossil Forest main site, Sexi, Peru, associated with the volcanic flow deposits.

Description: Growth rings present, marked by changes in fiber diameter and wall thickness and vessel arrangement (Fig. 13A, B). Wood diffuse porous. Vessels solitary $(54 \%)$ and in radial multiples of 2-3 (4-5) (Fig. 13A), round to oval in outline, tangential diameter $90 \pm 18 \mu \mathrm{m}$, frequency $\sim 23 / \mathrm{mm}^{2}$, perforations simple; intervessel pits alternate, oval (Fig. 13C), 3-4 $\mu \mathrm{m}$, apertures slit-like (and occasionally coalescent); vessel-ray parenchyma and -axial parenchyma pits bordered, similar to intervessel pits (Fig. 13E); vessel element length $225 \pm 60 \mu \mathrm{m}$. Fibers non-septate, thin- to very thick-walled, with minutely bordered pits in radial walls. Axial parenchyma scanty paratracheal to vasicentric, in strands of 2-4 (Fig. $13 \mathrm{H})$. Rays 1-4(-5)-seriate (Fig. 3F); uniseriate rays frequent, low (1-2 cells high) to high; low rays of mainly upright cells; multiseriate rays with procumbent body ray cells and 1-6 rows of square to upright marginal cells (Fig. 13D), with occasional sheath cells (Fig. 13F); height $367 \pm 141 \mu \mathrm{m}$, frequency $\sim 5 /$ tangential mm. Rays occasionally fused vertically or joined by uniseriate extensions. Light- to dark-colored contents in vessels (Fig. 13 B). Rhomboidal crystals in upright and procumbent ray parenchyma cells (Fig. 13G), often integumented. 


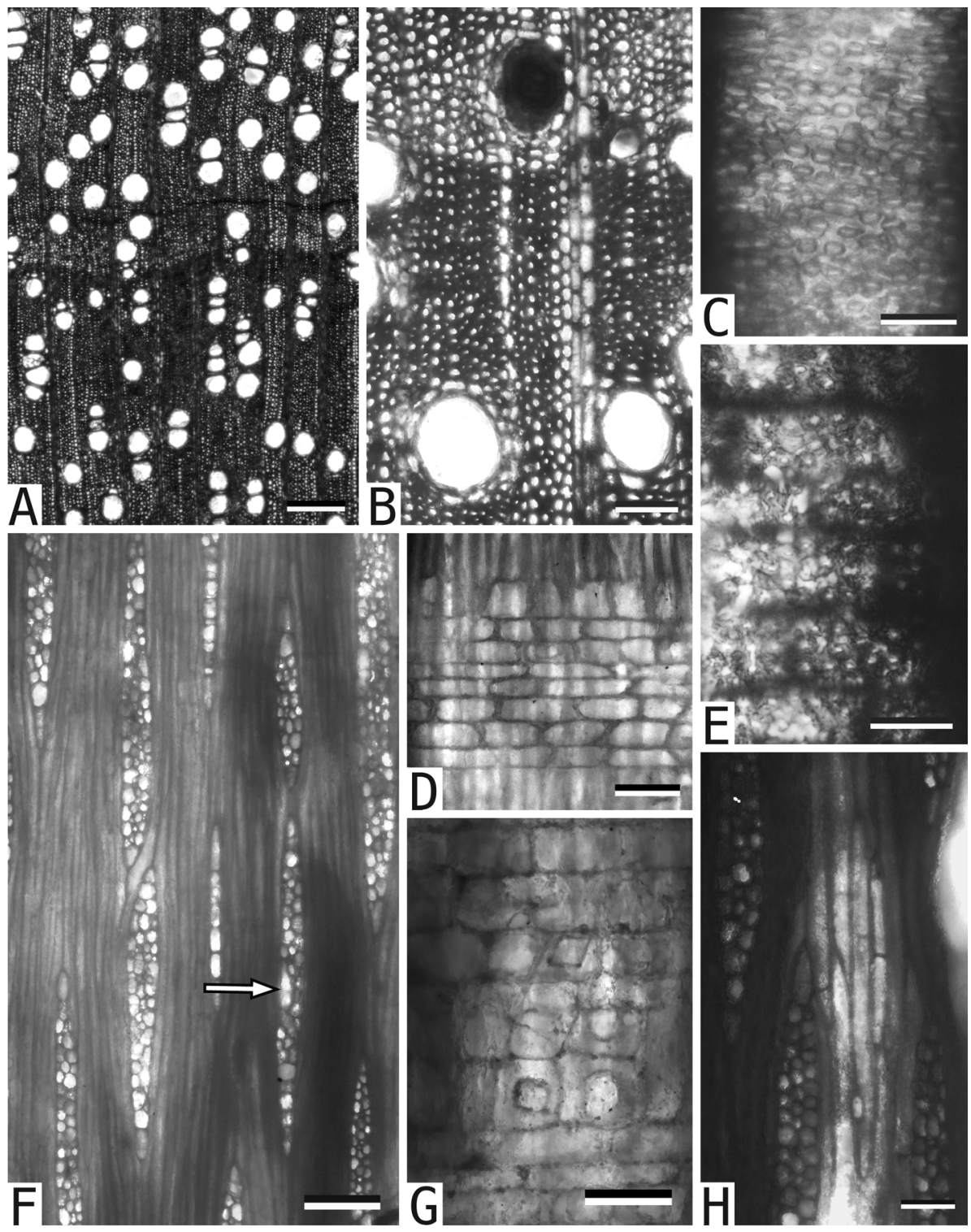

Figure 13. Zanthoxylum reynelii Woodcock, Meyer et Prado sp. nov. USM-S154. - A: Wood diffuse porous, TS. - B: Growth ring marked by changes in fiber wall thickness, scanty paratracheal and vasicentric parenchyma, vessel with dark contents, TS - - C: Intervessel pits alternate, TLS. - D: Ray with one row of upright marginal cells, RLS. - E: Vessel-ray parenchyma pits similar to intervessel pits, RLS. - F: Rays 1-4-seriate with sheath cells (arrow). - G: Crystals in ray parenchyma, RLS. $-\mathrm{H}$ : Axial parenchyma in strands of two, TLS. - Scale bars $=250 \mu \mathrm{m}$ in $\mathrm{A} ; 100 \mu \mathrm{m}$ in $\mathrm{F} ; 75 \mu \mathrm{m}$ in $\mathrm{B} ; 50 \mu \mathrm{m}$ in $\mathrm{D}, \mathrm{G}, \mathrm{H} ; 20 \mu \mathrm{m}$ in $\mathrm{C}, \mathrm{E}$. 
Affinity. In the InsideWood database, the combination of growth rings, minute intervessel pits, vessel ray pits similar to intervessel pits, non-septate fibers, diffuse to diffuse-in-aggregates parenchyma absent, axial parenchyma in strands of 2-4, elaborated paratracheal and widely banded parenchyma absent, rays not $>1 \mathrm{~mm}$, wood non-storied, and prismatic crystals (IAWA characters 1, 24, 30, 66, 91, 92, 136 with 65, $76,77,80,83,85,93,102$ and 118-122 absent) occurs only in Rutaceae (Balfourodendron, Fagaropsis, Harrisonia, Zanthoxylum). Rutaceae generally have diffuseporous wood with growth rings marked by marginal parenchyma and/or differences in fiber wall thickness, vessels with simple perforations and alternate pitting, vessel-ray parenchyma pits similar to intervessel pits, medium- to very thick-walled non-septate fibers, and scanty paratracheal parenchyma (Klaassen 1999; Appelhans et al. 2012). Very to moderately narrow vessels, intervessel pits minute to small, rays $<1 \mathrm{~mm}$ high, and absence of storying are also mentioned as typical (Metcalfe \& Chalk 1950), as are vessels retaining a rounded shape in multiples (Crawley 2001). The fossil is most similar to species of Zanthoxylum, a large pantropical genus distributed in a range of environments. New World Zanthoxylum, numbering $>70$ species (Reynel 2017), are variably diffuse to semi-ring or ring porous and typically have distinct growth rings, vessels solitary and in radial multiples of 2-4 (occasionally longer or in vessel clusters) and with deposits, marginal and confluent-banded parenchyma variably present, rays 1-5-seriate, and crystals, when present, in axial parenchyma and also in rays (often radially arranged) (Reynel 1995, 2017; León 2006; Arenas Flores et al. 2012); axial parenchyma strand length is generally 2-4 (León 2006; Aguilar-Alcántara et al. 2014; InsideWood 2004-onwards). Sheath cells are unusual in Rutaceae but have been noted in species from Africa/Madagascar (InsideWood 2004-onwards). Zanthoxylum is the only genus in an Old World and Oceania clade of Amyridoideae (Appelhans et al. 2018) with a range extending to the Americas. Other Neotropical Rutaceae, comprising the American clade of Amyridoideae (Groppo et al. 2012), differ from the fossil by some combination of parenchyma in strands of 4-8, rays 1-3-seriate, infrequent uniseriate rays, and crystals, when present, in axial parenchyma and generally not in rays (InsideWood 2004-onwards). The most similar of these, Balfourodenron, has crystals in rays but has marginal/banded apotracheal parenchyma and parenchyma in strands of (2-) 8. The many small trees and shrubs included in Rutaceae are not well represented in databases.

New World species of Zanthoxylum are tropical to temperate in occurrence and are most diverse on the eastern slopes of the Andes and in areas peripheral to the Amazon basin in successional to mature forests (Reynel 1995, 2017). They are medium sized to occasionally tall forest trees, small trees, and shrubs and are mostly deciduous.

Among fossil woods, Fagaroxylon Burgh, named for its similarity to temperate-latitude Fagaria (now subsumed in Zanthoxylum), shares with the fossil the characters of vessels solitary and in short radial multiples, simple perforations, alternate pitting, scanty paratracheal parenchyma, and heterocellular rays. Included taxa Fagaroxylon atkinsoniae Crawley, F. bavaricum Selmeier, and F. limburgense Burgh (all from the Miocene of Europe) have marginal parenchyma like the fossil but differ in having crystals in axial parenchyma and not rays; $F$. bavaricum also differs in its homocellular rays. 
Although showing similarities to woods in the fossil genus Fagaroxylon, closer correspondence to extant New World Zanthoxylum based on a range of characters leads us to name the fossil to a species within this genus.

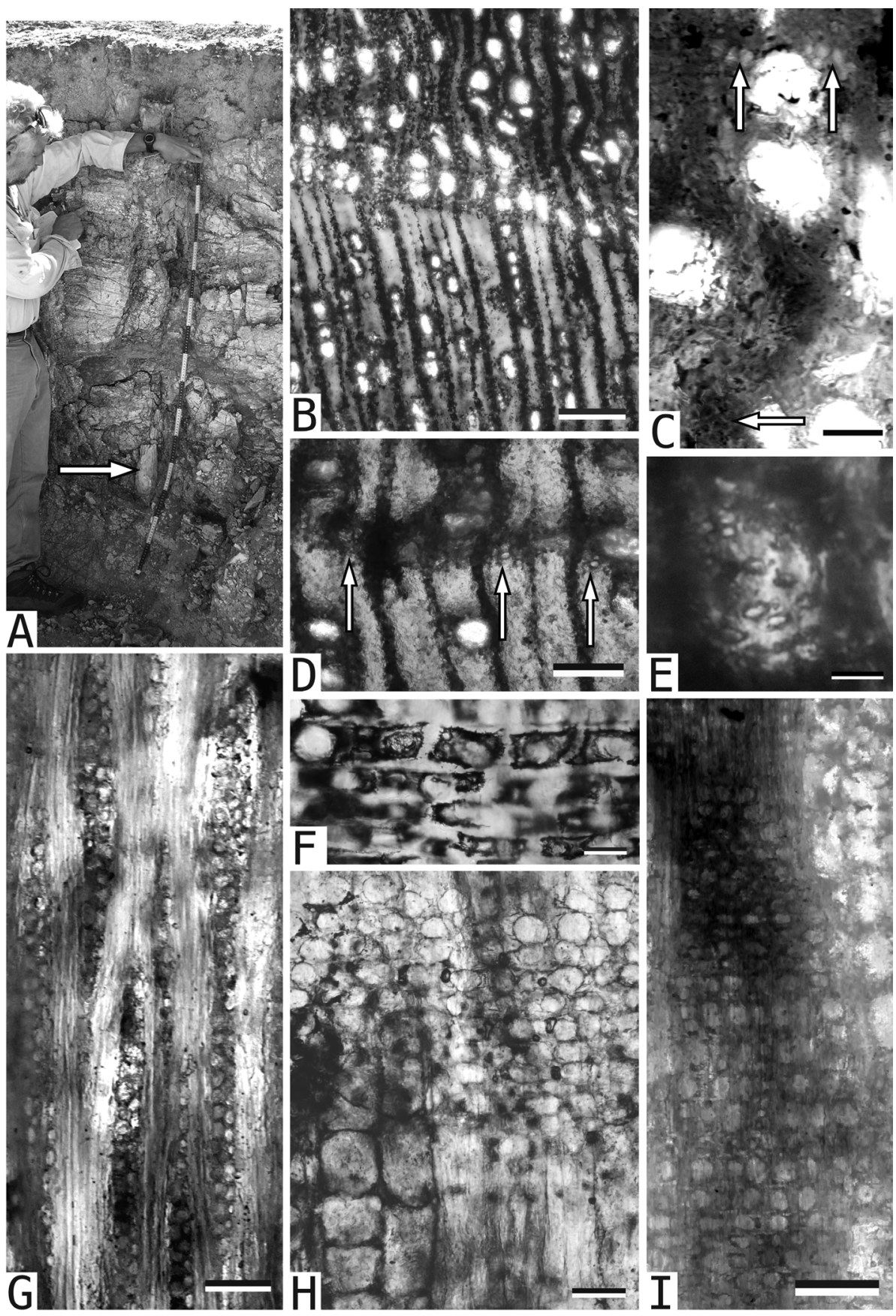




\section{Sapindaceae - Dodonaeoideae}

\section{Dodonaea Mill.}

Dodonaea piedra-chamana Woodcock, Meyer et Prado, sp.nov. (Fig. 14)

Diagnosis: Wood with distinct growth rings, diffuse to semi-ring porous. Vessels solitary and in radial multiples of 2-3, mean tangential diameter 50-100 $\mu \mathrm{m}$, perforations simple, intervessel pits alternate, vessel-ray parenchyma pits similar to intervessel pits. Fibers non-septate. Axial parenchyma paratracheal scanty, irregularly aliform, and marginal. Rays (1-)2(-3)-seriate; composed of weakly procumbent cells or with $1-3+$ rows of marginal square or upright cells or procumbent and square cells mixed throughout.

Etymology: The fossil is named for the fossil forest Piedra Chamana ("Stones of Chamana"). Chamana is the local name for Dodonaea viscosa, which is abundant at the site.

Holotype: USM-S45 (diameter $7.5 \mathrm{~cm}$ ) - small in situ tree (Fig. $14 \mathrm{~A}$ ).

Type locality: Piedra Chamana Fossil Forest main site, Sexi, Peru, associated with the ashfall deposit.

Description: Growth rings distinct, marked by changes in vessel frequency and marginal parenchyma (Fig. 14B, D). Diffuse to semi-ring porous, vessels solitary and in radial multiples of 2-3 (4), round to oval in outline, thick-walled, end walls horizontal, tangential diameter $54 \pm 16 \mu \mathrm{m}$, frequency $54 \pm 21 / \mathrm{mm}^{2}$, perforations simple, intervessel pits (circular to) oval, alternate, 6-7 $\mu \mathrm{m}$, with circular to oval apertures (Fig. 14E); vessel-ray parenchyma pits bordered, similar to intervessel pits; vessel elements very short $(89 \pm 40 \mu \mathrm{m})$. Fibers mostly non-septate, rarely with thin septae, minutely pitted, very thick-walled (Fig. 14C). Axial parenchyma paratracheal scanty, irregularly unilaterally paratracheal with short wings (Fig. 14C), and marginal in incomplete bands (Fig. 14D); in strands of 4+ cells. Rays (1-)2(-3)-seriate (Fig. 14G), made up of weakly procumbent cells or with $1-3+$ rows of marginal square or upright cells or procumbent and square cells mixed throughout (Fig. 14H, J); ray cells often circular and enlarged in tangential view; height $522 \pm 20 \mu \mathrm{m}$, estimated frequency $\sim 10$ / tangential $\mathrm{mm}$. Dark contents in ray parenchyma, generally at the cell periphery and extending into the cell wall (Fig. 14F); also in axial parenchyma. Phloem present in the outside of the stele but details of the structure not evident.

Affinity. The combination of small intervessel pits; vessels 50-100 $\mu \mathrm{m}$ and $40-100 /$ $\mathrm{mm}^{2}$; fibers with simple to minutely bordered pits and very thick-walled; rays 1-3-seriate of all procumbent cells, and wood non-storied (IAWA characters 25, 41, 49, 61, 70, 97,

Figure 14. Dodonaea piedra-chamana Woodcock, Meyer et Prado sp. nov. USM-S45. A: Specimen in situ in ashfall 9 (arrow) (scale marked in 10-cm increments). - B: Wood semiring porous, vessels solitary and in short radial multiples, TS. - C: Paratracheal parenchyma (vertical arrows), very thick-walled fibers (horizontal arrow), TS. - D: Marginal parenchyma (arrows), TS - E: Alternate intervessel pits, TLS. - F: Rays with dark contents at cell periphery, RLS. - G: Mainly biseriate rays, TLS. - H: Ray of procumbent cells, short vessel elements, RLS. - I: Weakly heterocellular ray, RLS. - Scale bars $=200 \mu \mathrm{m}$ in B; $100 \mu \mathrm{m}$ in D, I; $75 \mu \mathrm{m}$ in $\mathrm{G}, \mathrm{H} ; 50 \mu \mathrm{m}$ in $\mathrm{C} ; 25 \mu \mathrm{m}$ in $\mathrm{F} ; 10 \mu \mathrm{m}$ in $\mathrm{E}$. 
104 with 98 and 118-122 absent) occurs only in Combretaceae (Terminalia), Rutaceae (Helietta, Limonia, Murraya), and Sapindaceae (Dodonaea, Pappea). The fossil shares most characters with taxa in the Dodonaeoideae subfamily of Sapindaceae. Diffuse porous wood, vessels solitary and in short radial multiples with simple perforations, deposits in vessels, small intervessel pits, vessel ray pits similar to intervessel pits, scanty paratracheal parenchyma, predominantly uniseriate or predominantly biseriate rays, and wood non-storied are typical of Sapindaceae (Klaassen 1999). Rays are described as typically homocellular or weakly heterocellular, i.e., having squarish cells in a discontinuous row(s) at the margins or mixed throughout (Klaassen 1999). Fibers can be septate, non-septate, or mixed (Klaassen 1999). Crystals generally occur in axial parenchyma but were not seen in the fossil. The combination of vessel frequency $40-100 / \mathrm{mm}^{2}$, non-septate fibers, and rays 1-3-seriate is unusual in Sapindaceae, occurring only in temperate-latitude Acer and Dodonaeoideae (Dodonaea, Exotheca, Hippobromus, Hypelate). Of the latter, Exotheca and Hypelate are New World taxa and Dodonaea is a large genus ( 70 species) occurring mainly in Australia but including D. viscosa, which is distributed worldwide in the tropics and subtropics. These taxa are shrubs to small trees occurring in drier areas and as elements of strand or littoral vegetation. Dodonaea is most similar to the fossil. This genus has higher rays than most taxa in the subfamily (Klaassen 1999). Crystals in axial chains are conspicuously present in almost all Dodonaeoideae but can be absent or rare in D. viscosa $(\mathrm{H}-8833, \mathrm{H}-25517$, H-16408 - Aw; and material from Hawaii in collection of first author). Vessel elements are short for Dodonaea (Lui \& Noshiro 2003), although quite short in D. viscosa from Florida (Rock 1972) and in general often shorter in juvenile wood (Carlquist 1988). The features of the fossil are encompassed within the variability seen in D. viscosa, which has axial parenchyma scanty paratracheal and variably winged-aliform to confluent and marginal, rays mainly uniseriate to 2-4-seriate, growth rings and crystals present to absent, and fibers occasionally septate (Meylan \& Butterfield 1978; Li et al . 1995; Klaassen 1999; Lui \& Noshiro 2003). Dark contents in ray cell periphery and extending into cell walls are evident in Dodonaea (InsideWood 2004-onwards) but also occur in other Sapindaceae.

The fossil shares some features with Sapindoxylon Kräusel from the the Miocene of Asia, but Sapindoxylon has predominantly uniseriate rays. We are unaware of any fossil woods described as having similarity to Dodonaea.

Based on correspondence to Dodonaea and taxa in Sapindaceae - Dodonaeoideae, the fossil is named to a new species within the genus.

\section{DISCUSSION AND CONCLUSIONS}

These descriptions add to those published previously (Woodcock et al. 2017) and allow for discussion of the floristics and paleoecology of the assemblage, which includes 31 taxa of non-monocot angiosperms (Table 2).

Avicennia sexiensis Woodcock, Meyer et Prado occurs widely at the site and dominates the leaf impression flora. The mangrove genus Avicennia occurs in coastal mangrove, mixed freshwater, and riverine mangrove forests throughout the tropics; it often 
Table 2. Piedra Chamana fossil woods by family.

\begin{tabular}{|c|c|}
\hline Acanthaceae & Avicennia sexiensis \\
\hline Anacardiaceae & $\begin{array}{l}\text { cf. Mangifera } \\
\text { Anacardium incahuasi }\end{array}$ \\
\hline Apocynaceae & Tabernaemontana moralesii \\
\hline Combretaceae & cf. Thiloa \\
\hline Cordiaceae & $\begin{array}{l}\text { Cordia asenjoi } \\
\text { Cordia eocenensis } \\
\text { Cordia florifera }\end{array}$ \\
\hline Dipterocarpaceae & cf. Pseudomonotes \\
\hline Euphorbiaceae & Hura chancayensis \\
\hline Fabaceae & $\begin{array}{l}\text { Dalbergia santa-rosa } \\
\text { Cynometra grandis } \\
\text { Prioria elbaieae }\end{array}$ \\
\hline Lecythidaceae & Cariniana valverdei \\
\hline Lythraceae & $\begin{array}{l}\text { cf. Lagerstroemia I } \\
\text { cf. Lagerstroemia II } \\
\text { cf. Lagerstroemia III }\end{array}$ \\
\hline $\begin{array}{l}\text { Malvaceae - Bombacoideae } \\
\qquad \begin{array}{l}\text { - Bombacoideae/Malvoideae? } \\
\text { - Byttneroideae } \\
\text { - Grewioideae } \\
\text { - Sterculioideae }\end{array}\end{array}$ & $\begin{array}{l}\text { Ceiba archeopentandra } \\
\text { Ceiba huancabambiana } \\
\text { Ochroma pozoensis } \\
\text { Guazuma santacruzensis } \\
\text { Grewia americana } \\
\text { Grewinium canalisum } \\
\text { Luehea stratificata } \\
\text { Vasivaea weigendii } \\
\text { Sterculia matrum }\end{array}$ \\
\hline Melastomataceae & Miconioidea eocenica \\
\hline Muntingiaceae & Muntingia solipora \\
\hline Rubiaceae & Calycophyllum plengei \\
\hline Rutaceae & Zanthoxylon reynelii \\
\hline Sapindaceae & Dodonaea piedra-chamana \\
\hline
\end{tabular}

dominates where conditions are hypersaline. Avicennia germinans (L.) L., which this wood type most resembles, is the most widely occurring mangrove in the New World and also the most eurytopic (Saintilan et al.2014). No other mangrove species has been recovered. The mangrove genera Rhizophora and Laguncularia frequently occur with Avicennia in New World mangrove associations, generally sorting out along gradients relating to salinity, nutrients, or innundation time. Early Paleogene mangroves were dominated by Pelliciera and the mangrove palm Nypa, but sometime after the middle Eocene these genera became more restricted in occurrence (Pelliciera) or disappeared from the New World (Nypa) and Avicennia, Rhizophora, and Laguncularia became dominant (Rull 1998; Gee 2001). 
The co-occurrence of Avicennia leaves and trunks of non-monocot angiosperms and palms in situ in one location at the fossil site indicates that mixed freshwater mangrove forest is one of the vegetation types represented. Many of the fossil taxa are likely elements of this forest or associated seasonally flooded floodplain forests. These include: 1) Prioria (one species in Central America, adjacent areas of Colombia, and the upper Orinoco) and Vasivaea (two species in the Amazon and northern South America), both of which appear limited to flooded environments (Richards 1996; GBIF 2001-onwards); and 2) Ceiba, Cynometra, Hura, Ochroma, cf. Pseudomonotes, and Thiloa, all of which include species that are locally dominant (hyperdominant) or have their main occurrence in seasonally flooded New World tropical forests (ter Steege et al. 2006).

Floristically, the assemblage has similarities with the várzea forests of the western, Andean slopes of the Amazon basin and the northern Andes in Colombia and Venezuela. These forests are developed on rich alluvial soils associated with white water river systems and are distinct floristically from the forests of the Central Amazon and Guiana shield. Calycophyllum, Ceiba, Cordia, Guazuma, Hura, Luehea, Ochroma, and Sterculia include species considered characteristic of várzea (Kubitzki 1989). The abundance of Malvales (11 out of 31 wood types) - particularly Malvaceae but also including Muntingia (Muntingiaceae) and cf. Pseudomonotes (Dipterocarpaceae) may relate to the adaptations of Malvalean taxa to seasonally flooded, alluvial, and disturbed environments. Malvaceae are especially well represented in (high-water) low várzea in present-day South American forests (Wittmann et al.2010), and the Malvalean genera Guazuma, Ochroma, and Muntingia are closely associated with ruderal environments and early successional forests. Trees of the várzea are generally evergreen and can be quite large-statured, especially on upper terraces experiencing shorter flooded periods (high várzea, Wittmann et al. 2010). Of the represented taxa, Cariniana, Ceiba, and Cynometra species are generally large emergent trees. A $0.75 \mathrm{~m}$ diameter specimen of Cynometra is the largest fossil tree at the site. These three fossil taxa all have vessel diameters in the range 150-180 $\mu \mathrm{m}$, consistent with their being tall trees.

Although the fossils predate the main period of Andean uplift at $13 \mathrm{Ma}$, early phases of the Andean orogeny in Peru's western cordillera date to the Middle to Late Eocene (Mora et al. 2010) and could have produced fluvial-dominated environments of the type indicated here. Instability of the volcanic sediments upon which the vegetation was developed may also be a factor influencing the early-successional aspect of the assemblage. Marine incursions in western Amazonia during the Paleogene include the Pozo embayment, which extended from Colombia to northern Peru during the Eocene (Roddaz et al. 2010). The paleovegetation may have been similar to that in northern Venezuela where broadleaf evergreen and deciduous forests including Anacardium, Cariniana, Ceiba, and Hura intergrade with mangroves (Conde \& Alarcón 1993).

The majority of tree species in the flooded forests of the South American tropics extend into adjacent interfluvial/terra firme forests or are generalists occurring in a range of forest types (Wittmann et al. 2010). Several of the likely floodplain forest elements - Calycophyllum, Cariniana, Ceiba, Cynometra, Guazuma, Luehea - are also well represented or occur typically in dry or seasonal forests. And those taxa with modern representatives restricted to terra firme vegetation - Anacardium, Dalbergia, 
Cordia (3 wood types), Grewia, Zanthoxylum, Dodonaea - are also most prevalent in drier areas (Useful Tropical Plants Database, Gentry 1993). Occurrence of ringor semi-ring-porous woods (Dalbergia, Cordia - 3 wood types, and Lagerstroemia 2 wood types), a functional type not well represented in present-day tropical forests (Boura \& De Franceschi 2007), also points toward an interfluvial vegetation that was dry deciduous to semi-deciduous forest and in addition suggests a strongly seasonal precipitation regime that may have had no close analog in present-day South America.

The majority of the woods have affinities to New World taxa or groups, but discordant elements include 1) an anacardiaceous wood showing closest affinity to Mangifera, an Old World taxon; 2) three species of Lythraceae referred to Lagerstroemia, likewise an Old World genus; and 3) woods in Malvaceae - Grewioideae including one wood very similar to the Old World genus Grewia and an apparently extinct species (Grewinium canalisum) very similar to a Deccan Traps wood from the Cretaceous-Paleocene boundary. Mention might also be made of the wood type allied to the only dipterocarp in the South American flora (Pseudomonotes) and a basal clade (Monotoideae) occurring in Africa; this record may be part of the ultimate vicariance story if the dipterocarps, with an apparent Gondwana origin, rafted north with the Indian subcontinent to become the dominant trees of the Southeast Asia tropical forests (Ashton 2014).

In summary, the fossils of the Piedra Chamana Fossil Forest document the vegetation growing in coastal to near-coastal location in South America at $39 \mathrm{Ma}$ and the existence of vegetation types including coastal mangrove, mixed mangrove forest with Avicennia, diverse seasonally flooded freshwater forest with floristic similarities to modern várzea, and deciduous to semideciduous interfluvial non-flooded (terra firme) forest. Although the presence of taxa that are common and characteristic elements of the Neotropical flora indicates persistence over time of environments and associations, particularly seasonally flooded forest, the dry forest component of the vegetation shows a less clear correspondence to modern associations and may be especially significant as regards South American forest and climate history.

\section{ACKNOWLEDGEMENTS}

The authors thank Anaïs Boura and an anonymous reviewer for their comments on the manuscript. This research was supported by an American Philosophical Society grant to D. Woodcock and National Science Foundation grant 0403510 to D. Woodcock and H. Meyer.

\section{REFERENCES}

Acevedo Mallque M, Kikata Y. 1994. Atlas of Peruvian woods. National Agrarian University La Molina, Peru \& Nagoya University, Japan. 202 pp.

Aguilar-Alcántara M,Aguilar-Rodríguez S, Terrazas T. 2014. Anatomía de la madera de doce especies de un bosque mesófilo de montaña de Tamaulipas, México. Madera Bosques 20: 69-86.

Alverson WS, Whitlock BA, Nyffeler R, Bayer C, Baum DA. 1999. Phylogeny of the core Malvales: evidence from ndhF sequence data. Am. J. Bot. 86: 1474-1486. DOI: $10.2307 / 2656928$.

Appelhans MS, Richelt N, Groppo M, Paetzold, Wen J. 2018. Phylogeny and biogeography of the pantropical genus Zanthoxylum and its closest relative in the proto-Rutaceae group (Rutaceae). Mol. Phylo. Evol. 126: 31-44. https://doi.org/10.1016/j.ympev.2018.04.013. 
Appelhans MS, van Heuven BJ, Lens F, Baas P. 2012. Phylogenetic and ecological signals in the wood of Spathelioideae (Rutaceae). IAWA J. 33: 337-353. DOI: 10.1163/2294193290000099.

Arenas Flores F, Andrés-Hernández A, Terrazas T, Castañeda C. 2012. La madera de cinco especies de Zanthoxylum L. (Rutaceae) con distribución en México. Madera Bosques 18: $43-56$.

Ashton PS, Reinmar R, Kassim AR. 2014. On the forests of tropical Asia: lest the memory fade. Kew Publishing. 670 pp.

Baldin T, Siegloch AM, Marchiori JNC. 2016. Compared anatomy of species of Calycophyllum DC. (Rubiaceae). Rev. Árvore 40: 759-768. http://dx.doi.org/10.1590/0100-6762201 6000400020 .

Baum DA, DeWitt Smith S, Yen A, Alverson WS, Nyffeler R, Whitlock BA, Oldham RL. 2004. Phylogenetic relationships of Malvatheca (Bombacoideae and Malvoideae; Malvaceae sensu lato) as inferred from plastid DNA sequences. Am. J. Bot. 91: 1863-1871. https://doi.org/10.3732/ajb.91.11.1863.

Boura A, De Franceschi D. 2007. Is porous wood structure exclusive of deciduous trees? C.R. Palevol. 6: 385-391. https://doi.org/10.1016/j.crpv.2007.09.009.

Bremer B, Erikkson T. 2009. Time tree of Rubiaceae: Phylogeny and dating the family, subfamilies, and tribes. Int. J. Plant Sci. 170: 766-793. DOI: 10.1086/599077.

Brunken U, Muellner AN. 2012. A new tribal classification of Grewioideae (Malvaceae) based on morphological and molecular phylogenetic evidence. Syst. Bot. 37: 699-711. https:// doi.org/10.1600/036364412X648670.

Carlquist S. 1988. Comparative wood anatomy: systematic, ecological, and evolutionary aspects of dicotyledon wood. Springer, New York.

Carlquist S. 2005. Wood and bark anatomy of Muntingiaceae: a phylogenetic comparison within Malvales s.1. Brittonia 57: 59-67. https://doi.org/10.1663/0007-196X(2005)057[0059: WABAOM]2.0.CO;2.

Carvalho-Sobrinho JG, Alverson WS, Alcantara S, Queiroz LP, Mota AC, Baum DA. 2016. Revisiting the phylogeny of Bombacoideae (Malvaceae): Novel relationships, morphologically cohesive clades, and a new tribal classification based on multilocus phylogenetic analyses. Mol. Phylo. Evol. 101: 56-74. DOI: 10.1016/j.ympev.2016.05.006.

Chalk L, Chattaway MM. 1933. Perforated ray cells. Proc. R. Soc. London, Ser. B: 82-92. DOI: 10.1098/rspb.1933.0032.

Chattaway MM. 1933. Tile-cells in the rays of the Malvales. New Phytol. 32: 261-273.

Chattaway MM. 1937. The wood anatomy of the family Sterculiaceae. Phil. Trans. R. Soc. London Ser. B 228: 313-365.

Conde JE, Alarcón C. 1993. Mangroves of Venezuela. Conservation and sustainable utilization of mangrove-forests in the Latin American and African regions: Part I. Latin America. Mangrove. Eco.Tech. Repts. Ser. 2: 211-243.

Crawley M. 2001. Angiosperm woods from British Lower Cretaceous and Palaeogene deposits. Special Papers in Palaeontology, Palaeontological Assoc., London. 100 pp. https://doi. org/10.1017/S0016756802306502.

Détienne P, Jacquet P. 1983. Atlas d'identification des bois de l'Amazonie et des régions voisines. Centre Technique Forestier Tropical, Nogent s/Marne. 640 pp.

Détienne P, Loureiro AA, Jacquet P. 1983. Éstudo anatómico do lenho da familia Bombacaceae da América. Acta Amazon. 13: 831-867.

Duarte MC, Esteves GL, Salatino MLF, Walsh KC, Baum DA. 2011. Phylogenetic analyses of Eriotheca and related genera (Bombacoideae, Malvaceae). Syst. Bot. 36: 690-701. DOI: $10.1600 / 036364411 X 583655$. 
GBIF - Global Biodiversity Information Facility. 2001-onwards. http:///www.gbif.org (accessed $3 / 17 / 17)$.

Gee C. 2001. The mangrove palm Nypa in the geologic past of the New World. Wetlands Ecol. Manag. 9: 181-194. https://doi.org/10.1023/A:10111485.

Gentry AH. 1993. A field guide to the families and genera of woody plants of Northwest South America. Conservation International, Washington, DC. 895 pp.

Gregory M, Poole I, Wheeler EA. 2009. Fossil dicot wood names - an annotated list with full bibliography. IAWA J. Suppl. 6. 220 pp.

Groppo M, Kallunki JA, Pirani JR, Antonelli A. 2012. Chilean Pitavia more closely related to Oceania and Old World Rutaceae than to Neotropical groups: evidence from two cpDNA non-coding regions, with a new subfamilial classification of the family. PhytoKeys 19: 9-29. DOI: $10.3897 /$ phytokeys.19.3912.

IAWA Committee. 1989. IAWA List of microscopic features for hardwood identification. IAWA J. n.s. 10: 219-332.

InsideWood. 2004-onwards. Published on the Internet. http://insidewood.lib.ncsu.edu.

Jansen SE, Robbrecht H, Beekman H, Smets E. 2002. A survey of the systematic wood anatomy of the Rubiaceae. IAWA J. 23: 1-67. DOI: 10.1163/22941932-90000288.

Klaassen R. 1999. Wood anatomy of the Sapindaceae. IAWA J. Suppl. 2. 214 pp.

Kubitzki K. 1989. The ecogeographical differentiation of Amazonian inundation forests. Plant Syst. Evol. 162: 285-304. https://doi.org/10.1007/978-3-7091-3972-1_15.

León H WJ. 2006. Anatomía de la madera de 13 especies del orden Sapindales que crecen en el estado Merida, Venezuela. Acta Bot. Ven. 29: 269-296.

León H WJ. 2011. Anatomía de la madera de 31 especies de Rubiaceae en Venezuela. Acta Bot. Ven. 34: 347-379.

Lersten NR, Czlapinski AR, Curtis JD, Freckmann R, Horner HT. 2006. Oil bodies in leaf mesophyll cells of angiosperms: overview and a selected survey. Am. J. Bot. 93: 1731-1739. https://doi.org/10.3732/ajb.93.12.1731.

Li B, ter Welle BJH, Klaassen RKWM. 1995. Wood anatomy of trees and shrubs from China VII. Sapindaceae. IAWA J. 16: 191-215. DOI: 10.1163/22941932-90001403.

Lui J, Noshiro S. 2003. Lack of altitudinal trends in wood anatomy of Dodonaea viscosa (Sapindaceae), a species with a world-wide distribution. Am. J. Bot. 90: 532-539. https:// doi.org/10.3732/ajb.90.4.532.

Manchester SR, Miller RB. 1978. Tile cells and their occurrence in Malvalean fossil woods. IAWA Bull. 1978/2-3: 23-28.

Marinho RC, Mendes-Rodrigues C, Balao F, Ortiz PL, Yamagishi-Costa J, Bonetti M, Oliveira PE. 2014. Do chromosome numbers reflect phylogeny? New counts for Bombacoideae and a review of Malvaceae s.1. Am. J. Bot. 10: 1456-1465. https://doi.org/10.3732ajb. 1400248.

Metcalfe CR, Chalk L. 1950. Anatomy of the dicotyledons. 2 Vols. Clarendon Press, Oxford, U.K. 1500 pp.

Meylan BA, Butterfield BG. 1978. The structure of New Zealand woods. NZ. Dept. Sci. Ind. Res. Bull. 222: 1-250.

Michelangeli FA, Penneys DS, Giza J, Soltis D, Hils MH, Skean JD. 2004. A preliminary phylogeny of the tribe Miconieae (Melastomataceae) based on nrITS sequence data and its implications on inflorescence position. Taxon 53: 279-279. DOI: 10.2307/4135608.

Mora A, Baby P, Roddaz M, Parra M, Brusset S, Hermoza W, Espurt N. 2010. Tectonic History of the Andes and Sub-Andean Zones: Implications for the development of the Amazon Drainage Basin. In: Hoorn C, Wesselingh FP (eds.), Amazonia: Landscape and Species Evolution - A look into the past: 38-60. Wiley-Blackwell, Oxford/Hoboken. 
Nyffeler R, Baum DA. 2000. Phylogenetic relationships of the durians (Bombacaceae-Durioneae or Malvaceae/Helicteroideae/Durioneae) based on chloroplast and nuclear ribosomal DNA sequences. Plant Syst. Evol. 224: 55-82. https://doi.org/10.1007/BF00985266.

Pennington TD, Reynel C, Daza A. 2004. Trees of Peru. David Hunt, Sherborne, England. $848 \mathrm{pp}$.

Reynel C. 1995. Systematics of Neotropical Zanthoxylum (Rutaceae) with an account on the wood anatomy of the genus. Ph.D. dissertation, University of Missouri. $657 \mathrm{pp}$.

Reynel C. 2017. Zanthoxylum (Rutaceae). Flora Neotropica Monograph 117, New York Bot. Garden. 263 pp.

Richards PW. 1996. The tropical rain forest: an ecological study. Cambridge University. $574 \mathrm{pp}$.

Richter HG, Dallwitz MJ. 2000-onwards. Commercial timbers: descriptions, illustrations, identification, and information retrieval. Version: 25th June 2009. http://delta-intkey.com.

Rock BN. 1972. The woods and flora of the Florida Keys. Smithsonian Contributions to Botany no. $5.35 \mathrm{pp}$.

Roddaz M, Hermoza W, Mora A, Baby P, Parra M, Christophoul F, Brusset S, Espurt N. 2010. In: Hoorn C, Wesselingn FP (eds.), Cenozoic sedimentary evolution of the Amazonian foreland basin system: 61-88. Amazonia: Landscape and Species Evolution: A look into the past. Wiley-Blackwell.

Rull V. 1998. Middle Eocene mangroves and vegetation changes in the Maracaibo Basin, Venezuela. Palaios 13: 287-296. DOI: 10.2307/3515451.

Saintilan N, Wilson NC, Rogers K, Rajkaran A, Krauss KW. 2014. Mangrove expansion and salt marsh decline at mangrove poleward limits. Global Change Biol. 20: 147-157. https:// doi.org/10.1111/gcb.12341.

Sonsin JO, Gasson P, Machado SR, Caum C, Marcati CR. 2014. Atlas da diversidade de madeiras do cerrado paulista. Editora Fepaf, Botucatu Brasil. 423 pp.

Stevens PF. 2001-onwards. Angiosperm Phylogeny Website. Version 12, July 2012. http:// www.mobot.org/MOBOT/research/APweb/.

ter Steege H, Pitman NC, Phillips OL, Chave J, Sabatier D, Duque A, Molino JF, Prévost MF, Spichiger R, Castellanos H, Von Hildebrand P. 2006. Continental-scale patterns of canopy tree composition and function across Amazonia. Nature 443: 444-447. DOI: 10.1038/ nature05134.

ter Welle BJH, Koek-Noorman J. 1981. Wood anatomy of the Neotropical Melastomataceae. Blumea 27: 335-394.

The Plant List. 2010. Version 1. Published on the Internet. http://www.theplantlist.org.

Useful Tropical Plants database (tropical.theferns.info).

Van Vliet GJCM, Baas P. 1984. Wood anatomy and classification of the Myrtales. Ann. Missouri Bot. Gard. 71: 783-800.

Van Vliet GJCM, Koek-Noorman J, ter Welle BJH. 1981. Wood anatomy, classification and phylogeny of the Melastomataceae. Blumea 27: 463-473.

Wheeler EA. 2011. InsideWood - a web resource for hardwood anatomy. IAWA J. 321: 99-211. DOI: $10.1163 / 22941932-90000051$.

Wheeler EA, Srivastava R, Manchester SR, Baas P. 2017. Surprisingly modern: latest Cretaceous-earliest Paleocene woods of India. IAWA J. 38: 456-542. DOI: 10.1163/2294193220170174.

Whitlock BA, Bayer C, Baum DA. 2001. Phylogenetic relationships and floral evolution of the Byttnerioideae ("Sterculiaceae" or Malvaceae s.1.) based on sequences of the chloroplast gene, ndhF. Syst. Bot. 2001: 420-437. https://doi.org/10.1043/0363-6445-26.2. 420 . 
Wilkie P, Clark A, Pennington RT, Cheek M, Bayer C, Wilcock CC. 2006. Phylogenetic relationships within the subfamily Sterculioideae (Malvaceae/Sterculiaceae-Sterculieae) using the chloroplast gene ndhF. Syst. Bot. 31: 160-170. https://doi.org/10.1600/036364406775 971714.

Wittmann F, Schöngart J, Junk WJ. 2010. Phytogeography, species diversity, community structure and dynamics of central Amazonian floodplain forests. In: Junk WJ, Piedade MTF, Wittmann F, Schöngart J, Parolin P, Amazonian floodplain forests: 61-102. Springer, Netherlands. https://doi.org/10.1111/j.1365-2699.2006.01495.x.

Wittmann F, Schöngart J, Montero JC, Motzer T, Junk WJ, Piedade MT, Queiroz HL, Worbes M. 2006. Tree species composition and diversity gradients in white-water forests across the Amazon Basin. J. Biogeog. 33: 1334-1347.

Woodcock DW, Meyer H, Dunbar N. McIntosh W, Prado I, Morales G. 2009. Geologic and taphonomic context of El Bosque Petrificado Piedra Chamana (Cajamarca, Peru). Geol. Soc. Am. Bull. 121: 1172-1178. https://doi.org/10.1130/B26359.1.

Woodcock DW, Meyer H, Prado I. 2017. The Piedra Chamana fossil woods (Eocene, Peru). IAWA J. 38: 313-365. DOI: 10.1163/22941932-20170175. 